\title{
Unequal opportunity, unequal growth ${ }^{1}$
}

\author{
Gustavo A. Marrero \\ Departamento de Economía, Contabilidad y Finanzas (Universidad de La Laguna, Spain), EQUALITAS \\ and CEDESOG. Tel: +34 922277798. E-mail: gmarrero@ull.es \\ Juan Gabriel Rodríguez \\ Departamento de Análisis Económico I (Universidad Complutense de Madrid, Spain), EQUALITAS and \\ CEDESOG. Tel: +34 913942515. E-mail: juangabr@ucm.es \\ Roy van der Weide \\ World Bank Research Department. \\ Tel: +1 202473 1312. E-mail: rvanderweide@worldbank.org
}

\begin{abstract}
We argue that inequality can be both good and bad for growth, depending on what inequality and whose growth we are concerned with. Unequal societies may be holding back one segment of the population while helping another. Similarly, high levels of income inequality may be due to a variety of different factors, some of these may be good while others may be bad for growth. We test this hypothesis by "unpacking" both inequality and growth. Total inequality is decomposed into inequality of opportunity, due to observed factors that are beyond the individual's control, and residual inequality. Growth is measured at different steps of the income ladder to verify whether low, middle and top income households fare differently in societies with high (low) levels of inequality. In an application to the United States covering the period 1960 to 2010 we find that inequality of opportunity is bad for growth of the poor and good for the rich. When inequality of opportunity is controlled for, the importance of total income inequality is dramatically reduced. These results are robust to different measures of inequality of opportunity and econometric methods.
\end{abstract}

JEL Classification: D63, E24, O15, O40

Key Words: Inequality; Inequality of opportunity; growth; United States.

\footnotetext{
${ }^{1}$ Marrero and Rodríguez acknowledge the financial support from the Ministerio de Economía y Competitividad (Spain) under projects ECO2013-48884-C3-3-P and ECO2013-46516-C4-4-R, respectively, and from Comunidad de Madrid (Spain) under project S2015/HUM-3416-DEPOPORCM, and Fundación Caja Canarias (Spain). Rodríguez also appreciates the financial support of the Instituto de Estudios Fiscales (Spain). All views, and any errors or omissions are our own responsibility.
} 


\section{Introduction}

The Great Recession has brought inequality to the forefront of the economic debate again. Does the recent rise in inequality in the United States and Europe bode well for future growth prospects? The opinions are still very much divided on this question (see for example, Krueger, 2012, and Mankiw, 2013). We will argue that it matters whose growth prospects we are talking about, and what type of inequality we are concerned with.

A variety of different channels via which inequality could affect growth have been suggested over the years. This has inspired an extensive empirical literature that dates back to the 1990s. However, the results are mixed and largely inconclusive (i.e., see Banerjee and Duflo, 2003, and Panizza, 2002). A select number of studies have proposed that this ambiguity could be due to the fact that income inequality has distinct offsetting effects on subsequent growth that may cancel out in the aggregate (Barro, 2000; Voitchovsky, 2005). ${ }^{2}$

Two recent empirical studies in particular stand out. In an application to the United States, Marrero and Rodríguez (2013) find that a particular component of overall inequality, inequality of opportunity (IO), has a negative effect on growth. IO arguably reduces growth as it favors human capital accumulation by individuals with better social origins, rather than by individuals with more talent. The second study, van der Weide and Milanovic (2014), also an application to the United States, “unpacks” growth. It asks whether individuals at different steps of the socio-economic ladder fare differently in societies with high (low) levels of income inequality. They find that they do, namely that income inequality is bad for the growth prospects of the poor but good for the rich.

This paper disaggregates the inequality-growth relationship in order to address two important empirical questions: Can the effect of overall inequality on future income growth be attributed to IO? If indeed, is this particularly true for the poor, or does it concern households of all socio-economic classes?

We explore these questions using the IPUMS-USA database, as in van der Weide and Milanovic (2014), since it is the largest individual level database for the United States

\footnotetext{
${ }^{2}$ See also Galor and Moav (2004) who have proposed that the impact of inequality on growth changes with the replacement of physical capital by human capital accumulation as a main source of growth along the process of development.
} 
that covers the period 1960 to 2010. Our analysis is conducted at the level of states; we use the individual level data to compute state level measures of inequality of opportunity, overall income inequality, average income, and income growth (at selected percentiles). The same data is used to derive a set of controls including variables on demographics, education and employment. Additional controls are obtained from Marrero and Rodríguez (2013). Different methods are considered for the estimation of the dynamic panel data model (at the state level), specifically pooled OLS and different System-GMM regressions. As part of the robustness analysis we also consider different measures of IO (by varying both the choice of circumstances and the choice of outcomes along which inequality is being evaluated) and vary the choice of control variables.

Total income inequality is found to be negatively correlated with posterior growth of average income per capita when IO is not controlled for. Adding IO to the regression reveals that the correlation with future income growth is largely channeled through IO, leaving the effect of total inequality mostly insignificant.

When we re-examine the relationship between total inequality and income growth for low-, middle- and high income households, not controlling for IO, we find that the relationship is negative for the poor but positive for the rich. However, also here, the significance of total inequality is dramatically reduced when IO is added to the regression. This suggests that it is IO that is limiting the growth prospects of the poor rather than total inequality.

The exact channels via which IO might be impacting on future income growth remain to be identified. However, by concentrating on IO while tracking growth separately for the poor, the middle class and the rich, we made a necessary step forward in the dissection of the inequality-growth relationship.

The paper is organized as follows. Building on the literature of opportunity Section 2 develops the necessary distinction between overall inequality and inequality of opportunity. In Section 3 we introduce the database, including descriptives of the key variables used in the analysis. Section 4 presents the empirical model and the main results. Finally, Section 5 concludes.

\section{Inequality of opportunity: concept and measurement}


The modern theories of justice emphasize that income inequality is a composite measure of different components, among which inequality of opportunity refers to inequality stemming from circumstances, factors that are beyond the scope of individual responsibility like race, gender and socioeconomic background (Roemer, 1993; van de Gaer, 1993; Fleurbaey, 2008). This literature considers IO to be unjust and believes it warrants a public intervention that would help level the playing field. Moreover, it has been recently proposed that, while the impact of total inequality on growth is ambiguous, IO is growth deterring as, for example, it may favor human capital accumulation by individuals with better social origins rather than individuals with more talent. The potential misallocation of talent yields an underinvestment in human capital and, consequently, lower growth. ${ }^{3}$

To estimate IO, we adopt the ex-ante approach put forward by van de Gaer (1993) which partitions the population into types according to individuals' circumstances. IO is obtained as a measure of between-group inequality. Consider a finite population of individuals indexed by $i \in\{1, \ldots, N\}$. Following Checchi and Peragine (2010) and Ferreira and Gignoux (2011) the individual outcome, $y_{i}$, is assumed to be a function of the set of circumstances, $c_{i}$, and the amount of effort, $e_{i}$, such that: $y_{i}=g\left(c_{i}, e_{i}\right)$. Circumstances are exogenous by definition. Effort however will likely be influenced, among other factors, by circumstances. Accordingly, individual outcome may also be written as: $y_{i}=$ $g\left(c_{i}, e_{i}\left(c_{i}\right)\right)$.

Suppose the population is partitioned into mutually exclusive and exhaustive types denoted by $\Phi=\left\{J_{1}, \ldots, J_{T}\right\}$, where all individuals of a given type $t$ share the same circumstances. Let $e^{t}(\pi)=e\left(\pi, c^{t}\right)$ denote the level of effort exerted by an individual of type $t$ at the $\pi^{t h}$ quantile of the distribution of effort with $\pi \in[0,1]$. The level of outcome obtained by this individual is given by: $y^{t}(\pi)=g\left(c^{t}, e^{t}(\pi)\right)$. Equality of opportunity is achieved when the individual's outcome is independent of her social origins. Strictly speaking, this would demand that the following condition holds true:

\footnotetext{
${ }^{3}$ Bowles et al. (2005) have shown that even if individuals have high inborn talent, the likelihood of their being able to realize the benefits of that talent (for example, in terms of admission to university or access to employment) is strongly affected by initial conditions.
} 


$$
F^{t}(y)=F^{m}(y) \forall t, m,
$$

where $F^{t}(y)$ denotes the income distribution for individual's of type $t$. One could test for this by estimating the income distribution for each type and evaluating the significance of the difference. If one distribution dominates the other then this would offer unambiguous evidence against equality of opportunity. Unfortunately, relying on stochastic dominance is generally not guaranteed to rule one way or the other. Distributions can be significantly different yet cross each other in which case it is unclear whether one type is better off than the other (Atkinson, 1970).

To break potential ties, a practical alternative is to focus on a specific moment of the corresponding income distributions. Consider for example mean income. Let the vector $y=\left(y^{1}, \cdots, y^{T}\right)$ be a partition of outcomes into $T$ groups, where the vector $y^{t}$ contains the outcomes for all individuals of type $t$. Let $\bar{y}=\left(\bar{y}^{1}, \cdots, \bar{y}^{T}\right)$ denote the $N$ dimensional smoothened version of $y$ where each individual of type $t$ receives the mean income level for that type. A measure of IO can be obtained by evaluating $I O=I(\bar{y})$, where $I(\cdot)$ denotes a given inequality index, with $I(y)$ measuring total income inequality.

Of all the possible inequality indices that fulfill the basic principles found in the literature on inequality (progressive transfers, symmetry, scale invariance and replication of the population), only those of the Generalized Entropy class are additively decomposable into a between-group and a within-group component (Bourguignon, 1979 and Shorrocks, 1980). ${ }^{4}$ We use the Mean Logarithmic Deviation ( $\left.I_{M L D}\right)$, because it belongs to the Generalized Entropy class and has a path-independent decomposition. ${ }^{5}$ For an income distribution $y$, with mean $\overline{\bar{y}}$, the Mean Logarithmic Deviation is defined as:

$$
I_{M L D}(y)=\frac{1}{n} \sum_{i=1}^{n} \ln \left(\frac{\overline{\bar{y}}}{y_{i}}\right)
$$

where $n \in N$ is the number of income recipients. Using this inequality index, our IO estimates can be interpreted as the between-group component of total inequality.

\footnotetext{
${ }^{4}$ In the case that type income ranges overlap, which occurs in our case, the broadly used Gini coefficient is decomposable in three terms: a between-group component, a within-group component and a residual. The problem here is how to assign the last term to the between-group and within-group components.

5 The path-independent property implies that the result of the decomposition is independent of the component that is eliminated first, the between-group inequality or the within-group inequality (Foster and Shneyerov, 2000).
} 
Unfortunately, since one does not observe all relevant individual circumstances in practice, this measure of IO serves only as a lower bound. ${ }^{6}$

Finally, IO can be estimated either non-parametrically (Lefranc et al., 2008, and Rodríguez, 2008) or parametrically (Bourguignon et al., 2007, and Ferreira and Gignoux, 2011). The non-parametric approach makes minimal assumptions, but requires a sufficient amount of data. When the data is limited there is a premium for imposing additional structure by assuming a functional form for the function $g$. This would be the parametric approach. We will adopt the former, the non-parametric approach, as this takes full advantage of the fact that the database covers between 1 and 5 percent of the total population.

\section{The database and variables}

\subsection{The IPUMS USA database and sample design}

We use the IPUMS USA database which contains the largest sample of US population - between 1 and 5 percent of the total population - that covers a period of 50 years at regular decennial intervals: 1960, 1970, 1980, 1990, 2000 and 2010. ${ }^{7}$ The data is representative at the US state level. The obvious advantage of working with such a large data set is that sampling errors are reduced to a minimum. For their special features we do not consider the states of Alaska, Hawaii, District of Columbia and Puerto Rico in this analysis.

Total yearly income is obtained by aggregating incomes from 8 different sources: (i) wages, salary, commissions, bonuses or tips; (ii) self-employment income; (iii) interest, dividends, net rental income, or income from estate/trusts; (iv) social security or railroad retirement; $(v)$ supplemental security income; (vi) public assistance or welfare payments; (vii) retirement, survivor or disability pensions; and (viii) other regular sources of income, such as veterans payments, unemployment compensation, child support or

\footnotetext{
${ }^{6}$ Using the MLD index, the within-group inequality component could be seen as a proxy of inequality due to individual effort. Unfortunately, this measure contains residual elements arising from non-observed circumstances, luck and other measurement errors, which prevents us from using this term in the empirical analysis.

${ }^{7}$ The data covers 1 percent of the population for the years 1960-70 and 2010, and 5 percent of the population for the years 1980-2000.
} 
alimony. ${ }^{8}$ Income is made comparable over time by adjusting for inflation (all incomes are expressed in 2010 prices).

Income growth is evaluated using total household income per capita. Our measures of income inequality and inequality of opportunity are computed using individual income for the highest income earner within their household who are between the age of 30 and 50. The age restriction is included in order to mitigate the life-cycle composition effect on an individual's income (Roemer et al., 2003; Marrero and Rodríguez, 2012).

Three different measures of inequality of opportunity are being considered: inequality of opportunity in the acquisition of income; inequality of opportunity in acquiring occupational prestige; and social immobility in occupational prestige. The latter is measured as the correlation between the "occupational prestige” for a given individual and the average "occupational prestige" for individuals from an earlier generation belonging to the same race and the same state where the given individual was born. For the first two measures of inequality of opportunity we assume race and gender as circumstances. For race the following four groups are considered: non-Hispanic whites, Hispanic whites, blacks and others. Unfortunately, the IPUMS USA does not include information on parental education or income.

Race has been shown to be an important factor in determining an individual's success in life as measured by income or occupational prestige. Initial inequality in wealth between individuals from different racial backgrounds combined with barriers to accessing credit can generate significant degrees of inequality of opportunity (Ferreira and Gignoux, 2011; Marrero and Rodríguez, 2011). There is also evidence of continued differential treatment by race in the U.S. labor market, i.e. racial discrimination (see e.g. Bertrand and Mullainathan, 2004; Lang and Manove, 2011). Unequal opportunities between men and women are equally objectionable (Hederos et al., 2014; Calo-Blanco and García-Pérez, 2014). Other than being morally objectionable, affording individuals of different race and gender different opportunities may lead to a sub-optimal allocation of talent and a wasting of human resources. These inefficiencies are arguably harmful for growth.

\footnotetext{
${ }^{8}$ Unfortunately, the IPUMS USA database does not provide data on the individual components of income.
} 
The IPUMS USA database is also used to construct selected control variables. Following van der Weide and Milanovic (2014) we compute: (i) the percentage with a graduate degree among individuals between the age of 21 and 39 (Edu_ms); (ii) the share of women between the age of 24 and 65 who are out of the labor force (Olf_fem); and (iii) the population shares aged 15 or younger (Aged $0-15$ ) and aged 65 or older (Aged 65+). We expand the number of controls by also considering a selected set of the independent variables used in Marrero and Rodríguez (2013), which include: (iv) the share of (nonagricultural) employment in construction (Emp_cons), finance, insurance and real estate (Emp_finan), and government (Emp_gov); (v) the percentage change in nonagricultural employment over the preceding decade (Emp_growth); (vi) the fertility rate measured as the number of live births per 1,000 women 15-44 years old (Fertility); and (vii) public welfare expenditure as a percentage of state personal income (Welfare). ${ }^{9}$

\subsection{A first look at the data}

The four panels of Figure 1 plot the time-trends of the income growth rates for the poor, middle-class and the rich (top-left, top-right and bottom-left panels) as well as the time-trend of total income inequality (bottom-right panel) over the 50-year period. Lowand middle-income households have experienced a visibly different trend in income growth rates compared to top-income households. The last decade denotes an outlier arguably due to the 2007-2010 global financial crisis. Between 1970 and 2000 the poor and the middle-class have seen their growth rates decline while the rich have seen their growth rates increase. Consistent with this divergence in growth rates is the steady rise in total income inequality since the 1980s.

Figure 2 confirms that IO too has been increasing since the 1980s. The upward trend is most pronounced when only race is defined as circumstance; adding gender to the set of circumstances is found to flatten the trend. Interestingly, our measure of

\footnotetext{
${ }^{9}$ Employment data come from the Current Employment Statistics of the Bureau of Labor Statistics (U.S. Department of Labor: http://www.bls.gov/data/\#employment). 'Welfare' expenditures are collected from the U.S. Census Bureau, Annual Survey of State and Local Government Finances and Census of Governments (yearly data): https://www.census.gov/govs/local/historical_data.html. Fertility is obtained from the Vital Statistics of the United States: http://www.cdc.gov/nchs/products/vsus.htm.
} 
immobility in occupation prestige decreased significantly during the 60's and 70's but has remained constant since the 80’s.

The geography of inequality has also changed over the years, see Figure 3. In 1960 high levels of income inequality was mostly confined to the South with Mississippi ranking as the most unequal state. Fifty years later inequality in the South roughly equals the national average. High levels of inequality are now more likely to be found in the North-East and the West Coast, with New York ranking as the most unequal state. The same pattern is observed for inequality of opportunity (see Figure 4).

Figure 1. Box plots of growth and total inequality over time.
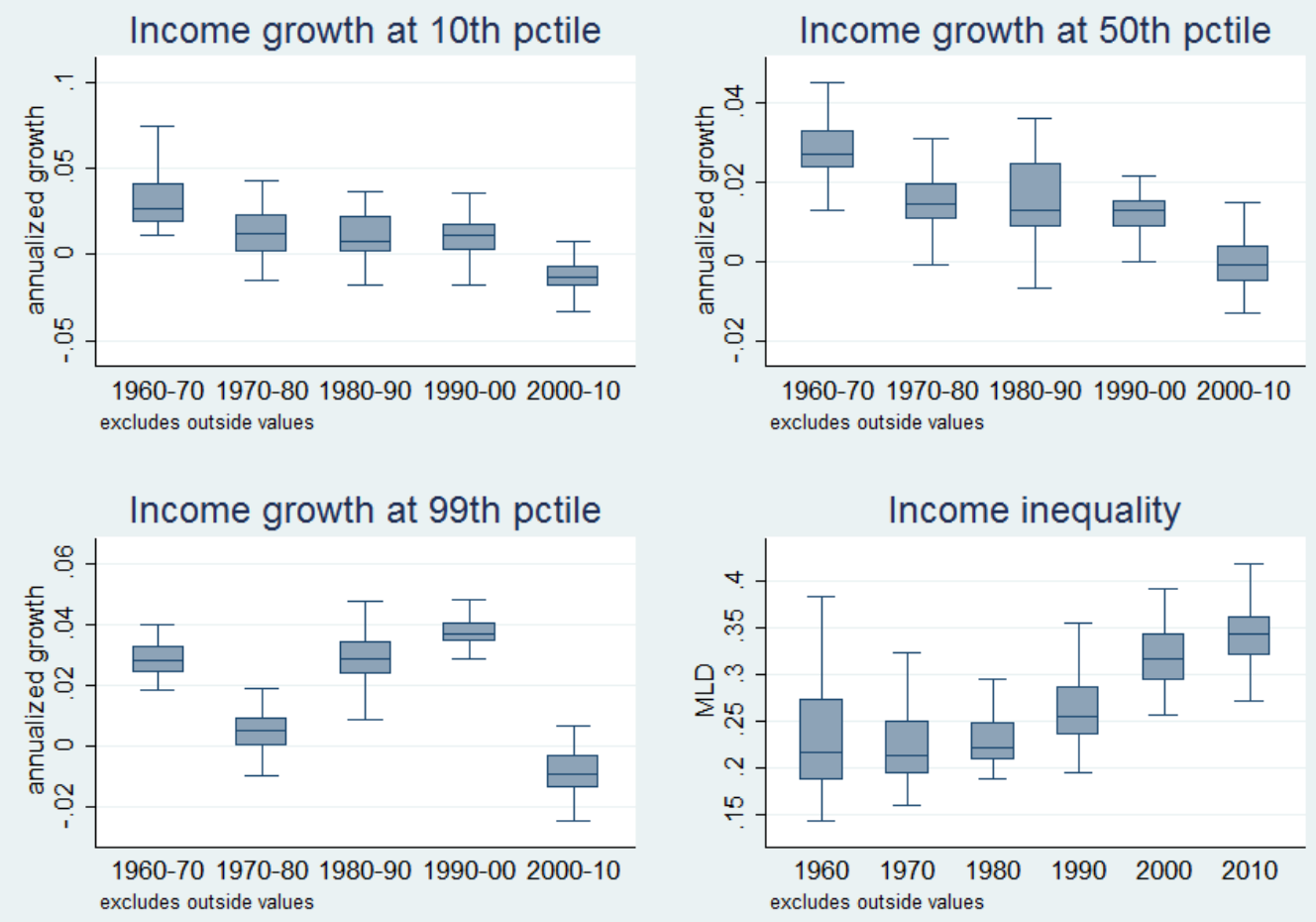
Figure 2. Box plots of IO over time.
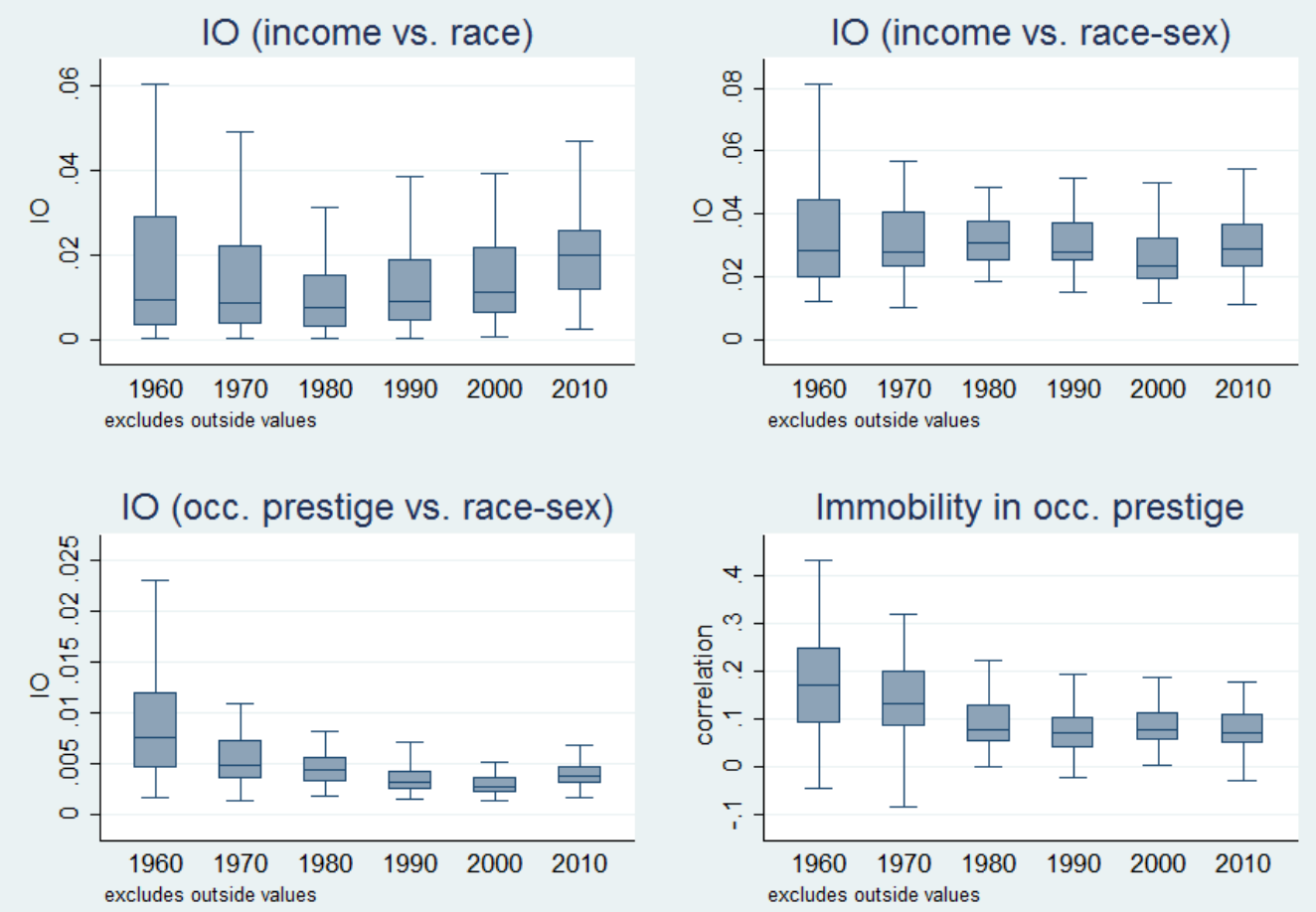

Figure 3. Inequality in 1960 versus 2010.

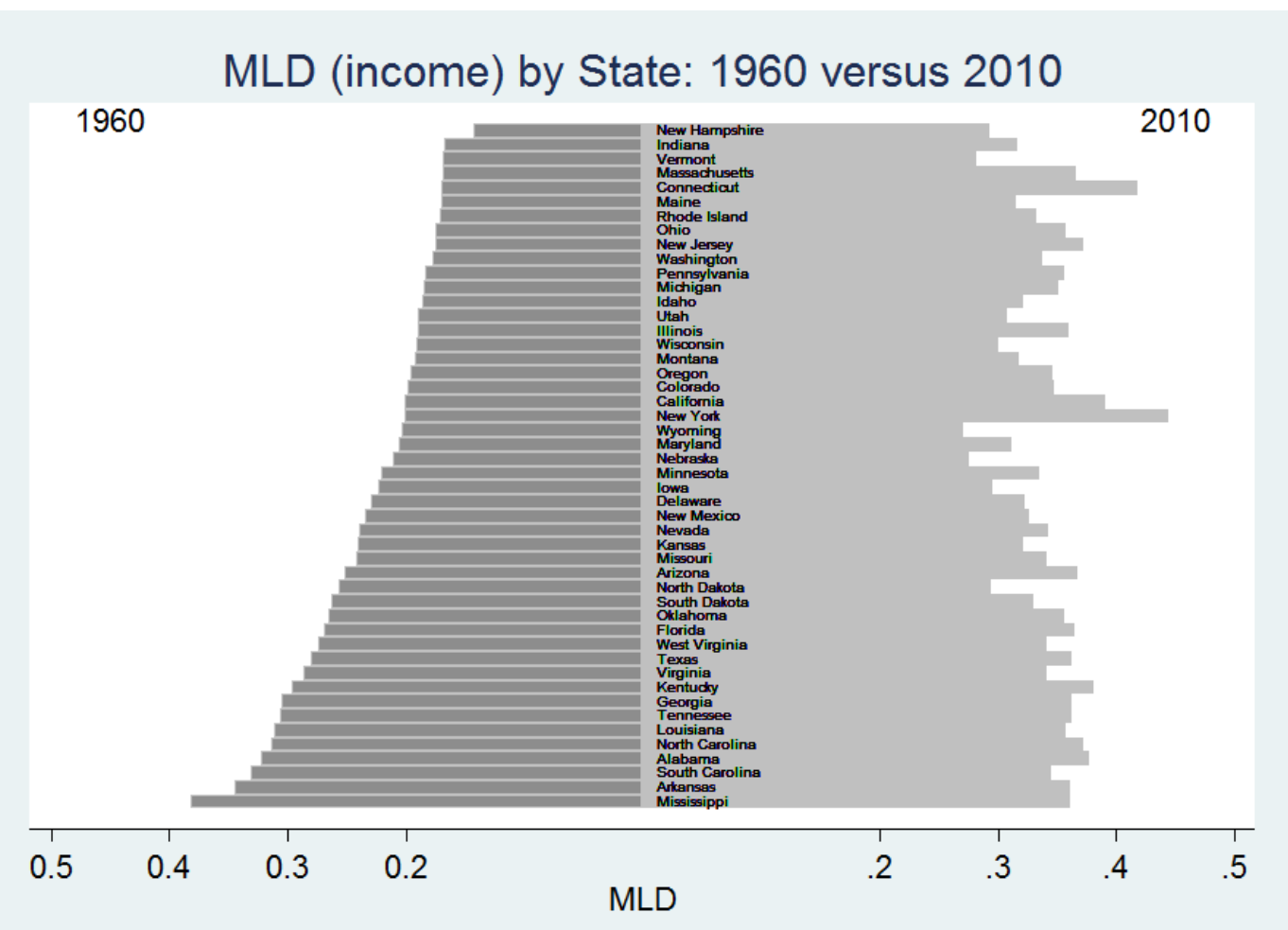


Figure 4. Inequality of Opportunity in 1960 versus 2010.

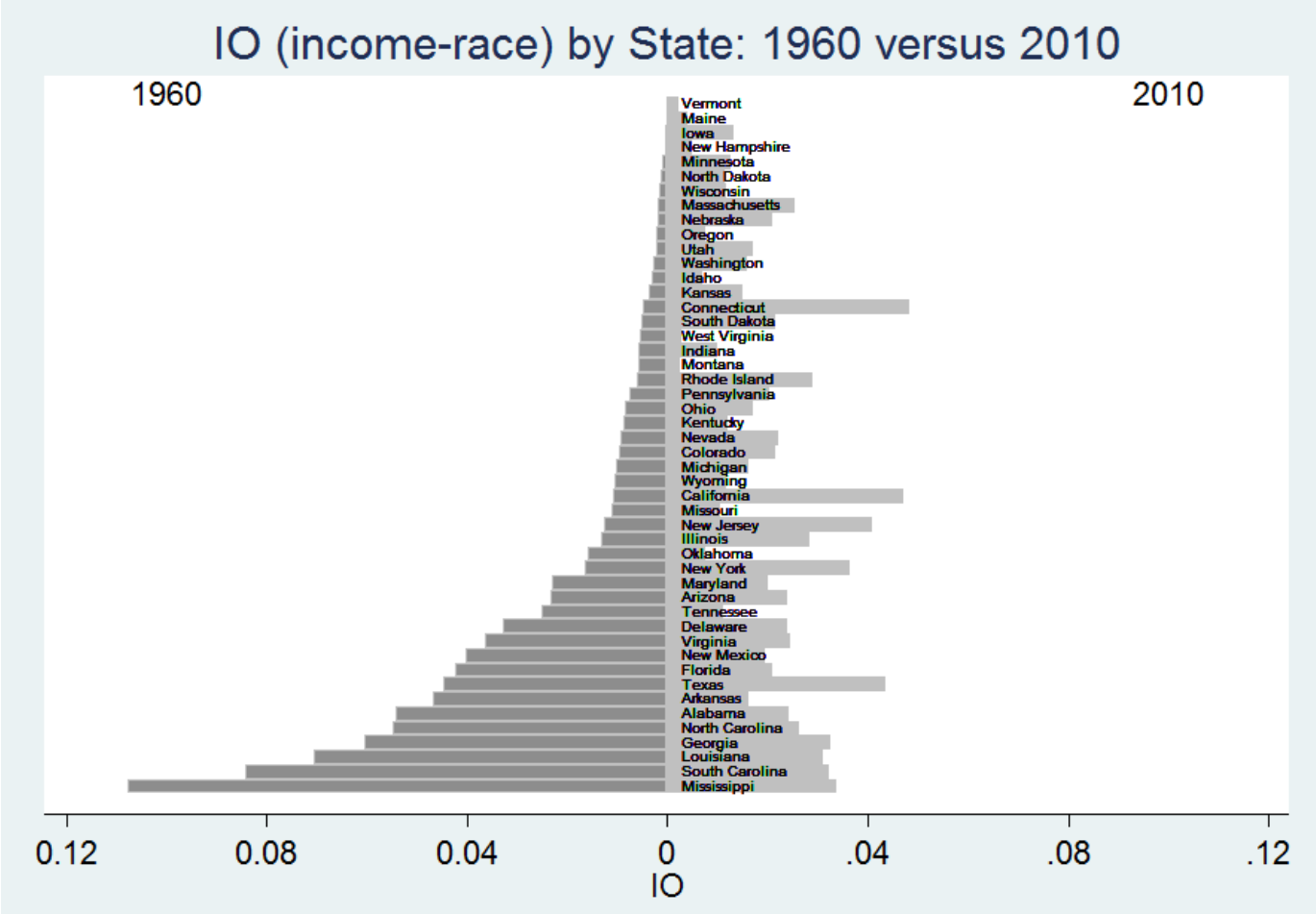

Let us also briefly inspect the time-trends in the selected-control variables. As Table 1 shows, the US has undergone a significant transformation over the 50 year period under consideration: (i) higher education has become more widespread; where 10 percent of young adults had a graduate degree in the 1960s, that number is closer to 25 percent 50 years later (Figure 5, panel a); (ii) labour force participation among women too shows a remarkable increase; where working women represented a minority in the 1960s and 1970s, their participation in the labour force is now at par with that of men (not shown here) (Figure 5, panel b); (iii) the country has steadily aged over time (with the \% of children steadily declining and the \% of elders steadily increasing); (iv) employment in the public sector shows a decline while employment in the financial sector has gradually increased; (v) growth in non-agricultural employment has stagnated as one would expect; (vi) public expenditure on welfare has steadily increased since the 60's; (vii) fertility shows a remarkable decrease between the 60's and the 90's, while it has stabilized between the 90's and 00's. 
Table 1. Selected controls over time (sample average across states)

\begin{tabular}{lllllll} 
& 1960 & 1970 & 1980 & 1990 & 2000 & 2010 \\
\hline Overall inequality (MLD) & 0.232 & 0.221 & 0.227 & 0.260 & 0.318 & 0.342 \\
IO (income vs race) & 0.020 & 0.016 & 0.010 & 0.013 & 0.015 & 0.020 \\
IO (income vs race-sex) & 0.037 & 0.035 & 0.032 & 0.031 & 0.026 & 0.031 \\
IO (occ. pres. vs race) & 0.006 & 0.003 & 0.002 & 0.002 & 0.002 & 0.003 \\
IO (occ. pres. vs race-sex) & 0.010 & 0.006 & 0.005 & 0.003 & 0.003 & 0.004 \\
Immobility in occ. pres. & 0.176 & 0.142 & 0.092 & 0.078 & 0.084 & 0.074 \\
Aged 0-15 (\%) & 0.339 & 0.314 & 0.253 & 0.242 & 0.230 & 0.212 \\
Aged 65+ (\%) & 0.089 & 0.100 & 0.112 & 0.125 & 0.128 & 0.137 \\
Edu_ms (\% grad. degree, age 21-39) & 0.093 & 0.133 & 0.194 & 0.211 & 0.236 & 0.282 \\
Women out of labor force (\%) & 0.606 & 0.528 & 0.415 & 0.299 & 0.288 & 0.262 \\
Empl. in constr. (\%)* & 0.059 & 0.051 & 0.051 & 0.046 & 0.051 &. \\
Empl. in finance (\%)* & 0.043 & 0.046 & 0.052 & 0.056 & 0.055 &. \\
Empl. in government (\%)* & 0.175 & 0.198 & 0.192 & 0.179 & 0.166 &. \\
Empl. growth (non-agri), preceding decade* & 0.248 & 0.343 & 0.382 & 0.209 & 0.236 &. \\
Public exp. on welfare / personal income* & 0.012 & 0.015 & 0.018 & 0.021 & 0.029 & - \\
Fertility* & 123.2 & 90.10 & 71.52 & 68.8 & 64.4 & - \\
\hline
\end{tabular}

(*) Data from Marrero and Rodriguez (2013) are available only until 2000.

Figure 5. Box plots of selected controls over time.

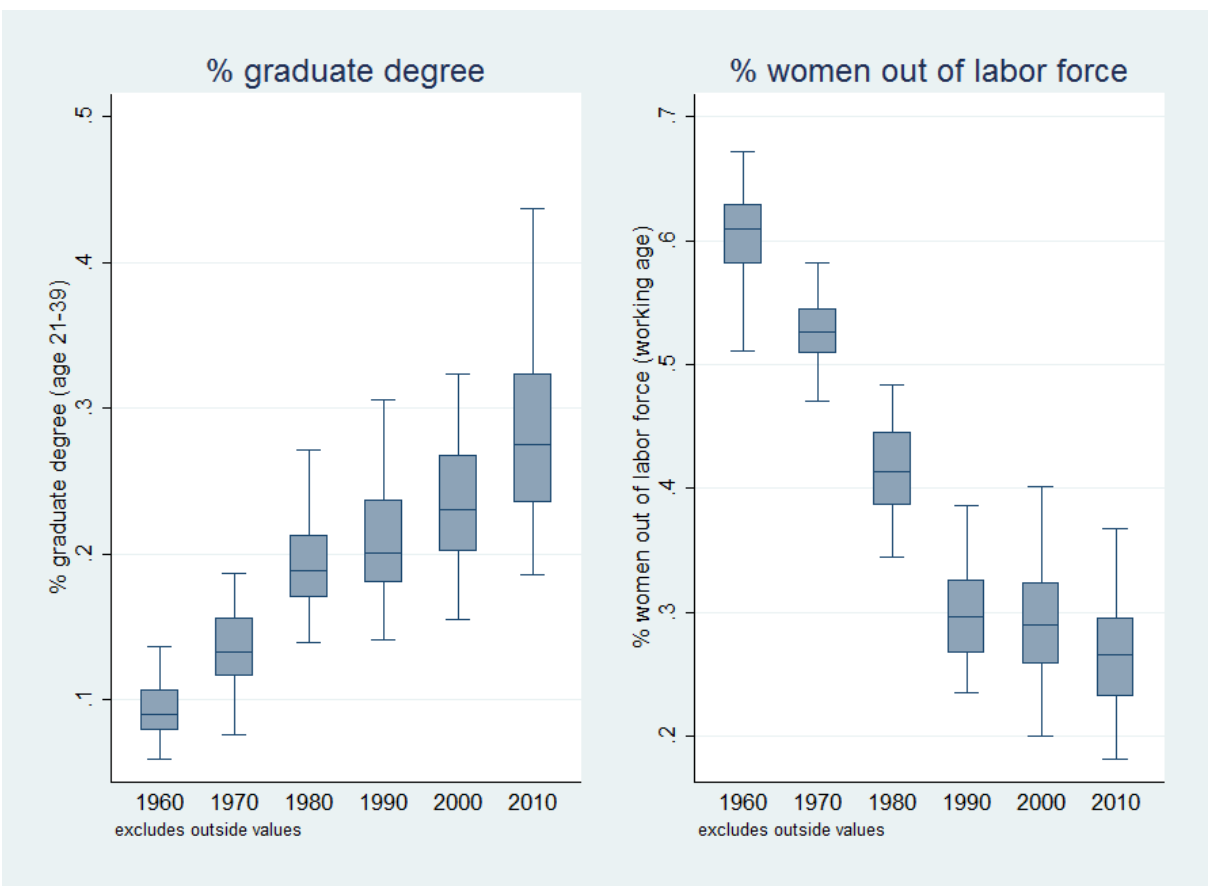




\section{Inequality of opportunity and growth at different steps of the income ladder}

We estimate a reduced-form growth equation (at different percentiles) with a set of inequality indices (total and IO) added to an otherwise standard set of growth determinants. The exact choice of control variables denote a combination of the controls used in Marrero and Rodríguez (2013) and van der Weide and Milanovic (2014).

\subsection{The reduced-form growth equation}

The reduced-form growth equation explores the link between overall inequality, inequality of opportunity and income growth for different segments of the population:

$$
y_{q i t}-y_{q i t-1}=\beta_{q} y_{q i t-1}+\gamma_{q} I_{i t-1}+\theta_{q} I O_{i t-1}+\omega_{q}^{T} x_{i t-1}+\alpha_{q i}+\delta_{q t}+\varepsilon_{q i t},
$$

where $y_{q i t}$ denotes log of per capita income for population segment $q$ in state $i$ at year $t$. In our application $q$ either refers to average income in the state or to a given percentile in the state's income distribution. We will consider the following selection of percentiles: 5th, 10th, 25th, 50th, 75th, 90th, 95th and 99th. The variables $\alpha_{q i}$ and $\delta_{q t}$ denote state (or region) and time-specific effects, $I_{i t}$ and $I O_{i t}$ are measures of overall inequality and inequality of opportunity in state $i$ at time $t, x_{i t}$ denotes a vector of control variables other than lagged income, and $\varepsilon_{q i t}$ is an iid error term. Income is always expressed in real terms, explanatory variables are always lagged one period (10 years in our case) and overall inequality and IO indices are as explained in the previous section. Equation (3) reduces to the specification from Marrero and Rodríguez (2013) when $y_{q i t}$ refers to the log of state GDP per capita, while the specification from van der Weide and Milanovic (2014) is obtained for $\theta_{q}=0$.

We will consider two different sets of controls: (a) the baseline specification with an economic set of controls derived from van der Weide and Milanovic (2014); ${ }^{10}$ and (b) an expanded set of controls that is obtained by adding variables from Marrero and Rodriguez (2013). The baseline specification includes the following state-level variables: "Edu_ms" (the percentage of individuals between the age of 21 and 39 years old with a graduate degree to control for human capital); “Olf_female” (the percentage of women between the age of 24 and 65 who are out of the labor force as a control for the functioning

\footnotetext{
${ }^{10}$ Note that in the original analysis, van der Weide and Milanovic (2014) considered also the percentage of education short-fall. We have preferred not to include this variable in the analysis because it is expected a close link between this variable and individual opportunity.
} 
of the labor market); “Aged 0-15” and “Aged 65+” (the percentage of individuals aged 15 or younger and aged 65 or older to control for demographics); lag of income to allow for convergence; as well as time-period dummies and region (Northeast, Midwest, South and West) or state dummies, depending on the specification. ${ }^{11}$ The expanded set of controls adds to this: “Emp_cons”, “Emp_finan”, “Emp_gover”, “Emp_grow”, "Fertility" and "Welfare", as described in Section 3.1. Our motivation for using the share of young adults with a graduate degree rather than considering all adults is that the former exhibits more variation over time, and hence carries more information up and above the state fixed effects. We aim to keep the number of controls that are highly persistent over time to a minimum in order to limit the co-linearity with the state fixed-effects. For this reason we have omitted the percent employed in farming, mining, manufacturing and transport (which are included in Marrero and Rodríguez, 2013).

We are especially interested in the sign of $\theta$, the parameter associated with IO in Equation (3). If the growth deterring effect of overall inequality (i.e., for poor households) is channeled through IO, then we should find that $\theta<0$. Once IO is controlled for, we hypothesize that $\gamma \geq 0$ because overall inequality is now a better proxy for the inequality due to individual effort (Marrero and Rodríguez, 2016a). It should be noted however that, as said above, our measure of IO under-estimates inequality of opportunity as we do not capture all relevant circumstances, in which case $\gamma$ would measure the combined effect of individual effort, unobserved circumstances and luck. As this combined effect need not be positive, a less demanding hypothesis is that $\gamma>\gamma(\theta=0)$, where $\gamma(\theta=0)$ denotes the value of $\gamma$ when IO is not controlled for. It is conceivable that IO has a different relationship with future growth at the top end of the income spectrum. This is an empirical question which we will address by estimating the IO-growth relationship along a wide range of state income percentiles.

\footnotetext{
${ }^{11}$ Northeast contains the following states: Connecticut, Maine, Massachusetts, New Hampshire, Rhode Island, Vermont, New Jersey, New York, and Pennsylvania. In the Midwest, we include the following: Illinois, Indiana, Michigan, Ohio, Wisconsin, Iowa, Kansas, Minnesota, Missouri, Nebraska, North Dakota, and South Dakota. South considers the following states: Delaware, Florida, Georgia, Maryland, North Carolina, Virginia, West Virginia, Alabama, Kentucky, Mississippi, Tennessee, Arkansas, Louisiana, Oklahoma, and Texas. Finally, we consider in the West: Arizona, Colorado, Idaho, Montana, Nevada, New Mexico, Utah, Wyoming, California, Oregon, and Washington.
} 


\subsection{Baseline specification with region fixed-effects: Robust pooled-OLS}

The between-group inequality component with income as outcome and race as circumstance denotes our benchmark IO measure. Table 2 presents robust pooled-OLS estimates for the baseline specification with region dummies. When IO is not controlled for, the coefficient for overall inequality is found to be negative and significant for the lower income percentiles, insignificant for the middle income percentiles, and positive and significant for the high income percentiles. Notably, when IO is controlled for, total inequality becomes insignificant as an explanatory factor for income growth along the income distribution; the inequality effect on income growth appears to be channeled through IO. It is the IO component that harms growth for the poor while helping income growth for the rich. In addition, it can be seen in Table 2 that the predictions concerning the coefficient of overall inequality $\gamma$ when IO is controlled for are fulfilled. Annex A presents a visual inspection of these findings.

Let us also briefly comment on the effects of the rest of controls on income growth across the different income percentiles. Higher levels of education (measured by the share of young adults who have a graduate degree) are positively correlated with growth across the income distribution. Likewise, female labor force participation helps growth, particularly for lower and middle income households (the effect is small and often insignificant for high income households). A larger share of the working age population also registers as a positive for future income growth. Finally, we find conditional convergence between states as the coefficient for the lag of income (in logs) is always negative and significant.

\section{INSERT TABLE 2 ABOUT HERE}

\subsection{Baseline specification with state fixed-effects: System-GMM estimation}

Pooled-OLS estimation with region-specific effects is vulnerable to endogeneity bias, specifically omitted variables bias. Allowing for state fixed effects should alleviate this concern to some degree. This however introduces a new challenge. Under the assumption that the (unobserved) state effects are correlated with the other independent variables that are part of the model, considering the state effects as part of the error term will introduce a bias. By the same token, eliminating the state effects by means of 
“differencing” also introduces a correlation between the (differenced) error term and the (differenced) control variables, and hence also introduces a bias. A commonly used method of estimation in this context is the System-GMM approach proposed by Arellano and Bover (1995) and Blundell and Bond (1998). ${ }^{12}$

The validity of the GMM-style instruments can be tested using an over identifying Hansen J-test. The proliferation of instruments (a common fact in System-GMM) tends to introduce additional over identifying problems however, which may call for a reduction of the instruments count (Roodman, 2009a). With this in mind, our baseline SystemGMM specification limits the number of over identifying restrictions by building a maximum of two instruments from each variable and lag distance. ${ }^{13}$ We initially consider $t-2$ and $t-3$ (for the first-difference equations) and $t-1$ (for the level equations) to construct the matrix of instruments. Because the test for second-order serial correlation in the first differences of the errors (the $m 2$ test) rejects the null in most of the specifications (see, for example, Table 3), the set of instruments is lagged one more period to $t-3$ and $t-4$ (for the first-difference equations) and to $t-2$ (for the level equations). This set of instruments remains valid even in the presence of second (but no higher) order serial correlation of the residuals, which is tested using an $\mathrm{AR}(3)$ test for the first differences of the errors (this test is also shown in Table 3).

Table 3 presents the estimates for our baseline System-GMM model (i.e., one-step with 2 lags for the instrument set starting at $t-3$ for the first difference equation). The main result obtained using robust pooled-OLS is largely maintained: IO deters the growth prospects of the poor, and if anything helps the rich to further grow their incomes. For average income (see first two columns in the Table), we find a negative and significant relationship with IO and a positive but insignificant relationship with total inequality. The System-GMM specification confirms the result from Marrero and Rodríguez (2013), namely that IO is bad for growth, but finds that this is mostly true for the poor, and not for the entire distribution.

\section{INSERT TABLE 3 ABOUT HERE}

\footnotetext{
${ }^{12}$ For instance, Acemoglu et al. (2015) have recently adopted the one-step System-GMM for the estimation of their dynamic panel model featuring growth, human capital, inequality and institutions.

${ }^{13}$ Considering 3 lags in the matrix of instruments leads to a Hansen test with a $p$-value that is almost equal to one, what is a clear symptom of a 'too-many instruments' problem (Roodman, 2009b).
} 
To test the robustness of our results, we consider alternative IO measures (this section), different GMM specifications (Annex B), and an expanded set of controls (next section). First, we re-estimate the System-GMM specification using alternative measures of IO, as described in Section 3, which includes: IO in the acquisition of income with not only race but also gender as individual circumstances; IO in the acquisition of occupational prestige for race and, for race and gender; and social immobility in occupational prestige. The results are presented in Table 4. Our main findings are in general preserved.

\subsection{Expanded set of controls with state fixed-effects: System-GMM estimation}

We extend the baseline model by expanding the set of controls with those also used in Marrero and Rodríguez (2013), namely: the shares of employment for construction, finance, insurance and real estate, and government; the percentage change in nonagricultural employment in the preceding decade; public expenditure in welfare as a percentage of personal income, and the fertility rate. Since expanding the set of controls also increases notably the number of instruments, using the baseline System-GMM specification (including 2 lags) leads to 'too-many instruments' problems (i.e., the pvalue of the Hansen test tends to 1.00; see Roodman, 2009a). We collapse the matrix of instruments to reduce the instrument count for the one-step System-GMM in this case, which denotes a standard approach.

As shown in Table 5, the negative and significant correlation between IO and growth of lower incomes and the positive and significant correlation between IO and growth of higher incomes prevails. While the coefficient of overall inequality continues to be positive and significant for the rich, it loses significance at the lower end of the income distribution. In addition, we find that: (i) the size of the public sector (in terms of employment) is positively correlated with income growth across the distribution, with larger effects observed for poor households; (ii) size of the construction sector undermines growth, particularly of lower incomes; (iii) size of the financial sector is positively correlated with growth of higher incomes, albeit insignificantly; (iv) expansion of non-agricultural employment is mostly insignificant; (v) public welfare expenditure lowers the growth prospects of top incomes but is insignificant in the growth regressions 
for the poor; while (vi) the fertility rate is clearly negatively correlated with growth, yet the size of the correlation appears to be slightly larger for lower income households.

It follows that the significance of overall inequality is somewhat sensitive to whether or not female labor force participation is controlled for. Table B2 (in the Annex) reproduces a version of Table 5 where "OLF-fem" is omitted as a control variable. This specification finds that overall inequality is significant at both ends of the income distribution, with inequality hurting income growth of the poor and helping growth of the rich. The results for the control variables are largely maintained.

\section{Discussion}

This study is the first to disaggregate the inequality-growth relationship by "unpacking" both inequality and growth. Income inequality is decomposed into inequality of opportunity and residual inequality. We unpack growth by tracking income growth at different steps of the income distribution. This allows for the possibility that the poor, the middle-class and the rich fare differently in societies with higher (or lower) levels of inequality of opportunity and total income inequality. It also allows us to verify the extent to which the relationship between income inequality and future income growth is channeled through inequality of opportunity.

We find that it is inequality of opportunity that is negatively correlated with future income growth of the poor. The same inequality of opportunity may also be positively correlated with growth at the top end of the income distribution. Our research advances the earlier studies by Marrero and Rodríguez (2013) and van der Weide and Milanovic (2014). The relationship between inequality of opportunity, inequality of efforts and growth in average income uncovered by Marrero and Rodríguez (2013) is found to describe the income growth of poor households better than growth of the average household. The relationship van der Weide and Milanovic (2014) found between total inequality and growth of the poor versus growth of the rich appears to be driven mostly by inequality of opportunity.

The present paper also provides additional robustness checks to Marrero and Rodríguez (2013) and van der Weide and Milanovic (2014). Marrero and Rodríguez (2013) used the PSID database which provides detailed information on individual 
circumstances (including parental education) but for a relatively small sample of households, and for a limited period of time (1970-2000). They opted to disregard states with fewer than 50 observations for any given decade, which ultimately limited their database to 26 states. Despite the extensive robustness analysis they carried out, the smallness of their survey samples makes their analysis vulnerable to sampling error. Instead, we use an entirely different database (the US community survey) that covers between 1 and 5 percent of the US population which reduces sampling error to a minimum and allows us to consider all US states and the larger time period 1960-2010. Our study also extends the analysis of van der Weide and Milanovic (2014) by considering a different measure of inequality (MLD based on individual income at reference age - aged 30 to 50 - rather than the Gini of income per capita), and above all, by adding an important omitted variable, namely inequality of opportunity.

It remains to be verified whether the findings from this study extend to other countries, including less developed economies. For instance, a developing country could possess a trap in the accumulation of human capital (Azariadis and Stachurski, 2005). If this is the case, an increase in any kind of inequality might be good for growth of the poor because it would help such a country exit this trap (Castelló-Climent and Mukhopadhyay, 2013). Replicating our study using data for other countries, including those with high levels of poverty, denotes an interesting venue for future empirical research.

Future research will hopefully also shed some light on the channels via which IO affects future income growth. It is conceivable that IO alludes to unequal access to good schooling or discrimination on the labor market, to name two candidate channels, either of which signifying inefficiencies that will disproportionally concern the growth prospects of the disadvantaged. The positive relationship between IO and income growth for the rich may be harder to explain. One possibility is that higher levels of IO may help to keep wages down for a significant share of the population which benefits those who are able to take advantage of the competitively priced supply of labor.

Finally, another empirical question worth exploring is how economic growth or development more broadly impacts on inequality of opportunity. In a preliminary investigation, Marrero and Rodríguez (2016b) find that raising the level of real GDP is associated with lowering levels of inequality of opportunity. If this is confirmed, then this may elude to the possibility of a positive cycle where economic growth lowers IO, and 
the reductions in IO further stimulate economic growth. However, more evidence on this will need to be obtained, including a precise analysis of the impact of pro-poor (and prorich) growth on inequality of opportunity. 
Table 2. Income growth and inequality by percentiles in the U.S.: estimated results using robust pooled-OLS.

\begin{tabular}{|c|c|c|c|c|c|c|c|c|c|c|c|c|c|c|c|c|c|c|}
\hline \multirow[b]{2}{*}{ Ineq., lag } & \multicolumn{2}{|c|}{ All sample } & \multicolumn{2}{|c|}{ Percentile 05} & \multicolumn{2}{|c|}{ Percentile 10} & \multicolumn{2}{|c|}{ Percentile 25} & \multicolumn{2}{|c|}{ Percentile 50} & \multicolumn{2}{|c|}{ Percentile 75} & \multicolumn{2}{|c|}{ Percentile 90} & \multicolumn{2}{|c|}{ Percentile 95} & \multicolumn{2}{|c|}{ Percentile 99} \\
\hline & $\begin{array}{l}-0.0215 \\
(-1.17)\end{array}$ & $\begin{array}{c}-0.00508 \\
(-0.22)\end{array}$ & $\begin{array}{c}-0.0760^{*} \\
(-1.62)\end{array}$ & $\begin{array}{l}0.0410 \\
(0.82)\end{array}$ & $\begin{array}{c}-0.0855^{* *} \\
(-2.19)\end{array}$ & $\begin{array}{l}-0.0176 \\
(-0.41)\end{array}$ & $\begin{array}{c}-0.0456^{*} \\
(-1.90)\end{array}$ & $\begin{array}{l}-0.0201 \\
(-0.72)\end{array}$ & $\begin{array}{l}-0.0156 \\
(-0.98)\end{array}$ & $\begin{array}{l}-0.0127 \\
(-0.60)\end{array}$ & $\begin{array}{c}0.00867 \\
(0.74)\end{array}$ & $\begin{array}{c}-0.00666 \\
(-0.39)\end{array}$ & $\begin{array}{l}0.0164 \\
(1.58)\end{array}$ & $\begin{array}{l}-0.0109 \\
(-0.69)\end{array}$ & $\begin{array}{c}0.0264^{* *} \\
(2.54)\end{array}$ & $\begin{array}{c}-0.00550 \\
(-0.36)\end{array}$ & $\begin{array}{c}0.0399 * * * \\
(3.20)\end{array}$ & $\begin{array}{c}-0.00939 \\
(-0.42)\end{array}$ \\
\hline IO, lag & & $\begin{array}{c}-0.0534 \\
(-1.10)\end{array}$ & & $\begin{array}{c}-0.431 * * * \\
(-4.48)\end{array}$ & & $\begin{array}{c}-0.257 * * * \\
(-3.33)\end{array}$ & & $\begin{array}{c}-0.0898^{*} \\
(-1.63)\end{array}$ & & $\begin{array}{c}-0.00958 \\
(-0.20)\end{array}$ & & $\begin{array}{l}0.0493 \\
(1.18)\end{array}$ & & $\begin{array}{c}0.0914^{* *} \\
(2.11)\end{array}$ & & $\begin{array}{c}0.110^{* *} \\
(2.59)\end{array}$ & & $\begin{array}{c}0.174^{* * *} \\
(2.81)\end{array}$ \\
\hline $\ln (y), \operatorname{lag}$ & $\begin{array}{c}-0.0512 * * * \\
(-9.43)\end{array}$ & $\begin{array}{c}-0.0508 * * * \\
(-9.30)\end{array}$ & $\begin{array}{l}-0.0495 * * * \\
(-8.03)\end{array}$ & $\begin{array}{l}-0.0511 * * * \\
(-8.68)\end{array}$ & $\begin{array}{l}-0.0543 * * * \\
(-9.22)\end{array}$ & $\begin{array}{l}-0.0558 * * * \\
(-9.66)\end{array}$ & $\begin{array}{l}-0.0507 * * * \\
(-9.46)\end{array}$ & $\begin{array}{l}-0.0510 * * * \\
(-9.49)\end{array}$ & $\begin{array}{l}-0.0519 * * * \\
(-9.55)\end{array}$ & $\begin{array}{l}-0.0518^{* * *} \\
(-9.45)\end{array}$ & $\begin{array}{l}-0.0455^{* * *} \\
(-8.92)\end{array}$ & $\begin{array}{l}-0.0466^{* * *} \\
(-8.77)\end{array}$ & $\begin{array}{l}-0.0402 * * * \\
(-9.01)\end{array}$ & $\begin{array}{l}-0.0424 * * * \\
(-9.10)\end{array}$ & $\begin{array}{l}-0.0325^{* * *} \\
(-7.41)\end{array}$ & $\begin{array}{l}-0.0348 * * * \\
(-7.78)\end{array}$ & $\begin{array}{l}-0.0353^{* * *} \\
(-6.35)\end{array}$ & $\begin{array}{l}-0.0382 * \\
(-6.97)\end{array}$ \\
\hline Edu_ms, lag & $\begin{array}{c}0.0899 * * * \\
(4.93)\end{array}$ & $\begin{array}{c}0.0893^{* * *} \\
(4.86)\end{array}$ & $\begin{array}{l}0.0554^{*} \\
(1.85)\end{array}$ & $\begin{array}{l}0.0611^{* *} \\
(2.20)\end{array}$ & $\begin{array}{l}0.0698 * * * \\
(2.72)\end{array}$ & $\begin{array}{l}0.0746^{* * *} \\
(2.99)\end{array}$ & $\begin{array}{l}0.0788^{* * *} \\
(4.03)\end{array}$ & $\begin{array}{l}0.0798^{* * * *} \\
(4.08)\end{array}$ & $\begin{array}{l}0.0934^{* * *} \\
(5.41)\end{array}$ & $\begin{array}{l}0.0932 * * * \\
(5.35)\end{array}$ & $\begin{array}{l}0.0904^{* * *} \\
(5.47)\end{array}$ & $\begin{array}{l}0.0926^{* * *} \\
(5.46)\end{array}$ & $\begin{array}{l}0.0883^{* * *} \\
(5.55)\end{array}$ & $\begin{array}{l}0.0927 * * * \\
(5.72)\end{array}$ & $\begin{array}{l}0.0760 * * * \\
(4.75)\end{array}$ & $\begin{array}{l}0.0811^{* * *} \\
(5.06)\end{array}$ & $\begin{array}{l}0.0787^{* * *} \\
(3.61)\end{array}$ & $\begin{array}{l}0.0841 * * * \\
(4.04)\end{array}$ \\
\hline Olf-fe male, lag & $\begin{array}{c}-0.0355^{* * *} \\
(-3.10)\end{array}$ & $\begin{array}{c}-0.0415^{* * *} \\
(-2.97)\end{array}$ & $\begin{array}{l}-0.0654^{* *} \\
(-2.57)\end{array}$ & $\begin{array}{l}-0.112 * * * \\
(-4.04)\end{array}$ & $\begin{array}{l}-0.0630 * * * \\
(-3.32)\end{array}$ & $\begin{array}{l}-0.0903 * * * \\
(-4.18)\end{array}$ & $\begin{array}{l}-0.0468 * * * \\
(-3.48)\end{array}$ & $\begin{array}{l}-0.0565 * * * \\
(-3.49)\end{array}$ & $\begin{array}{l}-0.0365 * * * \\
(-3.44)\end{array}$ & $\begin{array}{l}-0.0376^{* * *} \\
(-2.85)\end{array}$ & $\begin{array}{l}-0.0253^{* *} \\
(-2.59)\end{array}$ & $\begin{array}{l}-0.0194 \\
(-1.62)\end{array}$ & $\begin{array}{l}-0.0189 * \\
(-1.81)\end{array}$ & $\begin{array}{l}-0.00774 \\
(-0.63)\end{array}$ & $\begin{array}{l}-0.0215^{* *} \\
(-2.12)\end{array}$ & $\begin{array}{l}-0.00811 \\
(-0.69)\end{array}$ & $\begin{array}{l}-0.0171 \\
(-1.06)\end{array}$ & $\begin{array}{l}0.00347 \\
(0.19)\end{array}$ \\
\hline Aged 0-15, lag & $\begin{array}{c}-0.170 * * * \\
(-3.70)\end{array}$ & $\begin{array}{c}-0.161 * * * \\
(-3.43)\end{array}$ & $\begin{array}{l}-0.121^{*} \\
(-1.71)\end{array}$ & $\begin{array}{l}-0.0699 \\
(-1.07)\end{array}$ & $\begin{array}{l}-0.163^{* * *} \\
(-2.65)\end{array}$ & $\begin{array}{l}-0.136^{* *} \\
(-2.31)\end{array}$ & $\begin{array}{l}-0.143^{* * *} \\
(-2.81)\end{array}$ & $\begin{array}{l}-0.132 * * * \\
(-2.62)\end{array}$ & $\begin{array}{l}-0.175^{* * *} \\
(-3.87)\end{array}$ & $\begin{array}{l}-0.174 * * * \\
(-3.71)\end{array}$ & $\begin{array}{l}-0.162^{* * *} \\
(-4.15)\end{array}$ & $\begin{array}{l}-0.174 * * * \\
(-4.07)\end{array}$ & $\begin{array}{l}-0.161^{* * *} \\
(-4.87)\end{array}$ & $\begin{array}{l}-0.183^{* * *} \\
(-5.03)\end{array}$ & $\begin{array}{l}-0.142^{* * *} \\
(-4.65)\end{array}$ & $\begin{array}{l}-0.168^{* * *} \\
(-4.97)\end{array}$ & $\begin{array}{l}-0.144 * * * \\
(-3.91)\end{array}$ & $\begin{array}{l}-0.182 * * * \\
(-4.40)\end{array}$ \\
\hline Age 65+, lag & $\begin{array}{c}-0.0946 * * * \\
(-2.72) \\
\end{array}$ & $\begin{array}{c}-0.100^{* * *} \\
(-2.86) \\
\end{array}$ & $\begin{array}{l}-0.0181 \\
(-0.30) \\
\end{array}$ & $\begin{array}{l}-0.0780 \\
(-1.22) \\
\end{array}$ & $\begin{array}{l}-0.0604 \\
(-1.25) \\
\end{array}$ & $\begin{array}{l}-0.0981^{*} \\
(-1.94) \\
\end{array}$ & $\begin{array}{l}-0.0696^{*} \\
(-1.86) \\
\end{array}$ & $\begin{array}{l}-0.0822^{* *} \\
(-2.17) \\
\end{array}$ & $\begin{array}{l}-0.103^{* * *} \\
(-3.04) \\
\end{array}$ & $\begin{array}{l}-0.104^{* * *} \\
(-3.06) \\
\end{array}$ & $\begin{array}{l}-0.102^{* * * *} \\
(-3.29) \\
\end{array}$ & $\begin{array}{l}-0.1000^{* * *} \\
(-3.26) \\
\end{array}$ & $\begin{array}{l}-0.104^{* * *} \\
(-3.63)\end{array}$ & $\begin{array}{l}-0.100^{* * * *} \\
(-3.58) \\
\end{array}$ & $\begin{array}{l}-0.0889 * * * \\
(-2.77) \\
\end{array}$ & $\begin{array}{l}-0.0832 * * * \\
(-2.66)\end{array}$ & $\begin{array}{l}-0.0633 \\
(-1.65) \\
\end{array}$ & $\begin{array}{l}-0.0499 \\
(-1.32) \\
\end{array}$ \\
\hline Num.Obs & 240 & 240 & 240 & 240 & 240 & 240 & 240 & 240 & 240 & 240 & 240 & 240 & 240 & 240 & 240 & 240 & 240 & 240 \\
\hline R2 & 0.783 & 0.783 & 0.714 & 0.732 & 0.764 & 0.772 & 0.796 & 0.797 & 0.770 & 0.769 & 0.736 & 0.737 & 0.749 & 0.753 & 0.809 & 0.813 & 0.884 & 0.889 \\
\hline
\end{tabular}

Note. Robust $t$-statistics in parentheses. Balanced panel with 48 U.S. States, between 1960 and 2010 (every 10 years). The dependent variable is the annual growth rate of per capita income for each decade. Explanatory variables are all lagged one period (10 years). A constant term and time and regional dummies are also included in all models (estimations not shown in the table). 
Table 3. Income growth and inequality by percentiles in the U.S.: estimated results using robust System-GMM (baseline specification).

\begin{tabular}{|c|c|c|c|c|c|c|c|c|c|c|c|c|c|c|c|c|c|c|}
\hline \multirow[b]{2}{*}{ Ineq., lag } & \multicolumn{2}{|c|}{ All sample } & \multicolumn{2}{|c|}{ Percentile 05} & \multicolumn{2}{|c|}{ Percentile 10} & \multicolumn{2}{|c|}{ Percentile 25} & \multicolumn{2}{|c|}{ Percentile 50} & \multicolumn{2}{|c|}{ Percentile 75} & \multicolumn{2}{|c|}{ Percentile 90} & \multicolumn{2}{|c|}{ Percentile 95} & \multicolumn{2}{|c|}{ Percentile 99} \\
\hline & $\begin{array}{c}-0.0471^{*} \\
(-1.79)\end{array}$ & $\begin{array}{c}0.0275 \\
(0.93)\end{array}$ & $\begin{array}{l}-0.0512 \\
(-0.65)\end{array}$ & $\begin{array}{c}0.239 * * * \\
(2.84)\end{array}$ & $\begin{array}{c}-0.126^{* *} \\
(-2.06)\end{array}$ & $\begin{array}{c}0.0947^{*} \\
(1.85)\end{array}$ & $\begin{array}{c}-0.0800 * * \\
(-2.17)\end{array}$ & $\begin{array}{c}0.0264 \\
(0.77)\end{array}$ & $\begin{array}{c}-0.0380 * \\
(-1.86)\end{array}$ & $\begin{array}{c}0.0142 \\
(0.46)\end{array}$ & $\begin{array}{c}0.00587 \\
(0.35)\end{array}$ & $\begin{array}{l}0.0195 \\
(0.71)\end{array}$ & $\begin{array}{l}0.0240 \\
(1.50)\end{array}$ & $\begin{array}{c}-0.0159 \\
(-0.52)\end{array}$ & $\begin{array}{c}0.0415^{* *} \\
(2.37)\end{array}$ & $\begin{array}{c}-0.0314 \\
(-0.89)\end{array}$ & $\begin{array}{c}0.0628^{* * *} \\
(2.83)\end{array}$ & $\begin{array}{c}-0.000172 \\
(-0.00)\end{array}$ \\
\hline IO, lag & & $\begin{array}{c}-0.170^{* *} \\
(-2.25)\end{array}$ & & $\begin{array}{c}-0.783^{* * *} \\
(-3.20)\end{array}$ & & $\begin{array}{c}-0.601^{* * *} \\
(-3.45)\end{array}$ & & $\begin{array}{c}-0.263 * * * \\
(-2.78)\end{array}$ & & $\begin{array}{l}-0.110 \\
(-1.41)\end{array}$ & & $\begin{array}{l}-0.0130 \\
(-0.20)\end{array}$ & & $\begin{array}{l}0.118 \\
(1.59)\end{array}$ & & $\begin{array}{c}0.195^{* *} \\
(2.36)\end{array}$ & & $\begin{array}{l}0.166 \\
(1.53)\end{array}$ \\
\hline $\ln (y), \operatorname{lag}$ & $\begin{array}{c}-0.0634^{* * *} \\
(-6.37)\end{array}$ & $\begin{array}{c}-0.0618^{* * *} \\
(-6.20)\end{array}$ & $\begin{array}{c}-0.0472 * * * \\
(-4.18)\end{array}$ & $\begin{array}{c}-0.0491 * * * \\
(-3.81)\end{array}$ & $\begin{array}{c}-0.0634^{* * *} \\
(-5.93)\end{array}$ & $\begin{array}{c}-0.0659 * * * \\
(-5.44)\end{array}$ & $\begin{array}{c}-0.0614^{* * *} \\
(-5.65)\end{array}$ & $\begin{array}{c}-0.0620^{* * *} \\
(-5.42)\end{array}$ & $\begin{array}{c}-0.0684^{* * *} \\
(-6.05)\end{array}$ & $\begin{array}{c}-0.0663^{* * *} \\
(-5.89)\end{array}$ & $\begin{array}{c}-0.0585^{* * *} \\
(-6.77)\end{array}$ & $\begin{array}{c}-0.0563 * * * \\
(-6.53)\end{array}$ & $\begin{array}{c}-0.0498 * * * \\
(-7.16)\end{array}$ & $\begin{array}{c}-0.0498^{* * *} \\
(-7.39)\end{array}$ & $\begin{array}{c}-0.0402^{* * *} \\
(-6.08)\end{array}$ & $\begin{array}{c}-0.0414^{* * *} \\
(-6.64)\end{array}$ & $\begin{array}{c}-0.0357 * * * \\
(-3.71)\end{array}$ & $\begin{array}{c}-0.0372^{* * *} \\
(-3.95)\end{array}$ \\
\hline Edu_ms, lag & $\begin{array}{c}0.114^{* * *} \\
(4.09)\end{array}$ & $\begin{array}{c}0.112^{* * *} \\
(4.06)\end{array}$ & $\begin{array}{l}0.0545 \\
(1.24)\end{array}$ & $\begin{array}{l}0.0511 \\
(1.03)\end{array}$ & $\begin{array}{c}0.103^{* * *} \\
(2.75)\end{array}$ & $\begin{array}{c}0.102^{* *} \\
(2.60)\end{array}$ & $\begin{array}{c}0.0949 * * * \\
(3.07)\end{array}$ & $\begin{array}{c}0.0961^{* * *} \\
(2.95)\end{array}$ & $\begin{array}{c}0.124 * * * \\
(4.15)\end{array}$ & $\begin{array}{c}0.122^{* * *} \\
(4.16)\end{array}$ & $\begin{array}{c}0.106^{* * *} \\
(4.57)\end{array}$ & $\begin{array}{c}0.107^{* * *} \\
(4.72)\end{array}$ & $\begin{array}{c}0.0946^{* * *} \\
(4.71)\end{array}$ & $\begin{array}{c}0.103^{* * *} \\
(5.15)\end{array}$ & $\begin{array}{c}0.0832 * * * \\
(4.00)\end{array}$ & $\begin{array}{c}0.0957 * * * \\
(4.69)\end{array}$ & $\begin{array}{c}0.0673^{* *} \\
(2.23)\end{array}$ & $\begin{array}{c}0.0797^{* *} \\
(2.39)\end{array}$ \\
\hline Olf-female, lag & $\begin{array}{c}-0.0425^{* * *} \\
(-3.13)\end{array}$ & $\begin{array}{c}-0.0633^{* * *} \\
(-4.76)\end{array}$ & $\begin{array}{c}-0.0744^{* *} \\
(-2.30)\end{array}$ & $\begin{array}{c}-0.162 * * * \\
(-4.52)\end{array}$ & $\begin{array}{c}-0.0656^{* *} \\
(-2.39)\end{array}$ & $\begin{array}{c}-0.132 * * * \\
(-5.49)\end{array}$ & $\begin{array}{c}-0.0657 * * * \\
(-3.64)\end{array}$ & $\begin{array}{c}-0.0959 * * * \\
(-5.28)\end{array}$ & $\begin{array}{c}-0.0505^{* * *} \\
(-3.72)\end{array}$ & $\begin{array}{c}-0.0642^{* * *} \\
(-4.34)\end{array}$ & $\begin{array}{c}-0.0354^{* * *} \\
(-2.85)\end{array}$ & $\begin{array}{c}-0.0374 * * * \\
(-3.01)\end{array}$ & $\begin{array}{c}-0.0265^{* *} \\
(-2.01)\end{array}$ & $\begin{array}{l}-0.0123 \\
(-0.89)\end{array}$ & $\begin{array}{c}-0.0278^{*} \\
(-1.85)\end{array}$ & $\begin{array}{c}-0.00163 \\
(-0.11)\end{array}$ & $\begin{array}{l}-0.0315 \\
(-1.65)\end{array}$ & $\begin{array}{c}-0.00614 \\
(-0.29)\end{array}$ \\
\hline Aged 0-15, lag & $\begin{array}{c}-0.250 * * * \\
(-3.07)\end{array}$ & $\begin{array}{c}-0.225 * * * \\
(-3.02)\end{array}$ & $\begin{array}{l}-0.150 \\
(-1.09)\end{array}$ & $\begin{array}{l}-0.157 \\
(-1.20)\end{array}$ & $\begin{array}{c}-0.209 * \\
(-1.70)\end{array}$ & $\begin{array}{c}-0.213^{*} \\
(-1.80)\end{array}$ & $\begin{array}{c}-0.217^{* *} \\
(-2.27)\end{array}$ & $\begin{array}{c}-0.213^{* *} \\
(-2.27)\end{array}$ & $\begin{array}{c}-0.270^{* * *} \\
(-3.41)\end{array}$ & $\begin{array}{c}-0.246 * * * \\
(-3.29)\end{array}$ & $\begin{array}{c}-0.258 * * * \\
(-4.06)\end{array}$ & $\begin{array}{c}-0.226 * * * \\
(-4.04)\end{array}$ & $\begin{array}{c}-0.245^{* * *} \\
(-4.34)\end{array}$ & $\begin{array}{c}-0.218^{* * *} \\
(-4.72)\end{array}$ & $\begin{array}{c}-0.235^{* * *} \\
(-3.81)\end{array}$ & $\begin{array}{c}-0.207 * * * \\
(-4.29)\end{array}$ & $\begin{array}{c}-0.210^{* * *} \\
(-3.07)\end{array}$ & $\begin{array}{c}-0.194^{* * *} \\
(-3.40)\end{array}$ \\
\hline Age 65+, lag & $\begin{array}{c}-0.0969 * \\
(-1.69) \\
\end{array}$ & $\begin{array}{c}-0.119 * * \\
(-2.02) \\
\end{array}$ & $\begin{array}{l}-0.147 \\
(-1.47) \\
\end{array}$ & $\begin{array}{c}-0.250^{*} \\
(-1.97) \\
\end{array}$ & $\begin{array}{l}-0.102 \\
(-1.14) \\
\end{array}$ & $\begin{array}{c}-0.186 * \\
(-1.77) \\
\end{array}$ & $\begin{array}{c}-0.0404 \\
(-0.64) \\
\end{array}$ & $\begin{array}{c}-0.0794 \\
(-1.22) \\
\end{array}$ & $\begin{array}{r}-0.0857 \\
(-1.54) \\
\end{array}$ & $\begin{array}{c}-0.0995^{*} \\
(-1.82) \\
\end{array}$ & $\begin{array}{c}-0.104^{* *} \\
(-2.08) \\
\end{array}$ & $\begin{array}{c}-0.112^{* *} \\
(-2.38)\end{array}$ & $\begin{array}{c}-0.106^{* *} \\
(-2.15) \\
\end{array}$ & $\begin{array}{c}-0.105^{* *} \\
(-2.35) \\
\end{array}$ & $\begin{array}{c}-0.0761 \\
(-1.56) \\
\end{array}$ & $\begin{array}{c}-0.0692 \\
(-1.55) \\
\end{array}$ & $\begin{array}{c}-0.0381 \\
(-0.69) \\
\end{array}$ & $\begin{array}{c}-0.0372 \\
(-0.66) \\
\end{array}$ \\
\hline Num.Obs. & 240 & 240 & 240 & 240 & 240 & 240 & 240 & 240 & 240 & 240 & 240 & 240 & 240 & 240 & 240 & 240 & 240 & 240 \\
\hline hansen (p-val) & 0.343 & 0.765 & 0.283 & 0.586 & 0.418 & 0.798 & 0.423 & 0.757 & 0.368 & 0.676 & 0.308 & 0.682 & 0.474 & 0.708 & 0.303 & 0.614 & 0.542 & 0.857 \\
\hline m1(p-val) & 0.00 & 0.00 & 0.00 & 0.00 & 0.00 & 0.00 & 0.00 & 0.00 & 0.00 & 0.00 & 0.00 & 0.00 & 0.00 & 0.00 & 0.00 & 0.00 & 0.00 & 0.00 \\
\hline m2(p-val) & 0.00630 & 0.0119 & 0.00687 & 0.00890 & 0.00288 & 0.00607 & 0.0154 & 0.0372 & 0.00609 & 0.0102 & 0.0109 & 0.0146 & 0.00454 & 0.00653 & 0.180 & 0.165 & 0.0882 & 0.0884 \\
\hline AR(3)(p-val) & 0.111 & 0.142 & 0.124 & 0.243 & 0.195 & 0.442 & 0.0457 & 0.0959 & 0.119 & 0.149 & 0.256 & 0.260 & 0.544 & 0.651 & 0.341 & 0.437 & 0.990 & 0.761 \\
\hline Num.States & 48 & 48 & 48 & 48 & 48 & 48 & 48 & 48 & 48 & 48 & 48 & 48 & 48 & 48 & 48 & 48 & 48 & 48 \\
\hline Num.Instr. & 53 & 61 & 53 & 61 & 53 & 61 & 53 & 61 & 53 & 61 & 53 & 61 & 53 & 61 & 53 & 61 & 53 & 61 \\
\hline
\end{tabular}

Note. See Note in Table 2. A constant term and time dummies are included in all models (estimations not shown in the table). Estimations are by one-step System-GMM, reducing the number of lags to just 2 . Tests $m 1$ and $m 2$ are for first- and second-order serial correlation in the first-differenced residuals. Both are asymptotically N(0,1) distributed under the null of no serial correlation. Since most $p$-values of the $m 2$ test are below $0.10, t-2$ instruments are invalid. Thus, for the first difference equations, we use instruments starting at $t-3$. The test for the existence of an AR(3) in the first-difference residuals is shown to check for the validity of these instruments. The Hansen over-identifying restrictions test is asymptotically distributed as a chi-square with degrees of freedom equal to the number of instruments minus the number of parameters to be estimated. The $p$-value reported is for the null hypothesis of instruments validity. A $p$-value above 0.10 is symptom of instruments validity. 
Table 4. Income growth and inequality by percentiles in the U.S.: estimated results using robust System-GMM (alternative measures of IO)

\begin{tabular}{|c|c|c|c|c|c|c|c|c|c|c|c|c|c|c|c|c|c|c|}
\hline & \multicolumn{2}{|c|}{ All sample } & \multicolumn{2}{|c|}{ Percentile 05} & \multicolumn{2}{|c|}{ Percentile 10} & \multicolumn{2}{|c|}{ Percentile 25} & \multicolumn{2}{|c|}{ Percentile 50} & \multicolumn{2}{|c|}{ Percentile 75} & \multicolumn{2}{|c|}{ Percentile 90} & \multicolumn{2}{|c|}{ Percentile 95} & \multicolumn{2}{|c|}{ Percentile 99} \\
\hline & \multicolumn{18}{|c|}{ IO index: income between-groups inequality (race \& gender) } \\
\hline Ineq., lag & $\begin{array}{c}-0.0471 * \\
(-1.79)\end{array}$ & $\begin{array}{c}-0.00324 \\
(-0.08)\end{array}$ & $\begin{array}{l}-0.0512 \\
(-0.65)\end{array}$ & $\begin{array}{c}0.208^{* *} \\
(2.16)\end{array}$ & $\begin{array}{c}-0.126^{* *} \\
(-2.06)\end{array}$ & $\begin{array}{l}0.0645 \\
(0.94)\end{array}$ & $\begin{array}{c}-0.0800^{* *} \\
(-2.17)\end{array}$ & $\begin{array}{c}-0.0235 \\
(-0.49)\end{array}$ & $\begin{array}{c}-0.0380^{*} \\
(-1.86)\end{array}$ & $\begin{array}{l}-0.0274 \\
(-0.65)\end{array}$ & $\begin{array}{c}0.00587 \\
(0.35)\end{array}$ & $\begin{array}{l}-0.0124 \\
(-0.33)\end{array}$ & $\begin{array}{l}0.0240 \\
(1.50)\end{array}$ & $\begin{array}{l}-0.0378 \\
(-0.95)\end{array}$ & $\begin{array}{c}0.0415^{* *} \\
(2.37)\end{array}$ & $\begin{array}{c}-0.0471 \\
(-1.09)\end{array}$ & $\begin{array}{c}0.0628^{* * *} \\
(2.83)\end{array}$ & $\begin{array}{l}-0.0195 \\
(-0.36)\end{array}$ \\
\hline IO, lag & & $\begin{array}{l}-0.135 \\
(-1.33)\end{array}$ & & $\begin{array}{c}-0.726^{* *} \\
(-2.66)\end{array}$ & & $\begin{array}{c}-0.552^{* * *} \\
(-2.72)\end{array}$ & & $\begin{array}{l}-0.179 \\
(-1.52)\end{array}$ & & $\begin{array}{l}-0.0431 \\
(-0.44)\end{array}$ & & $\begin{array}{l}0.0339 \\
(0.39)\end{array}$ & & $\begin{array}{l}0.151 \\
(1.61)\end{array}$ & & $\begin{array}{c}0.215^{* *} \\
(2.24)\end{array}$ & & $\begin{array}{c}0.196^{*} \\
(1.71)\end{array}$ \\
\hline \multirow[t]{2}{*}{ Hansen(p-val) } & 0.343 & 0.709 & 0.283 & 0.680 & 0.418 & 0.706 & 0.423 & 0.714 & 0.368 & 0.741 & 0.308 & 0.643 & 0.474 & 0.708 & 0.303 & 0.711 & 0.542 & 0.870 \\
\hline & \multicolumn{18}{|c|}{ IO index: occupation between-groups ine quality (race) } \\
\hline Ineq., lag & $\begin{array}{c}-0.0471 * \\
(-1.79)\end{array}$ & $\begin{array}{l}0.0334 \\
(1.10)\end{array}$ & $\begin{array}{l}-0.0512 \\
(-0.65)\end{array}$ & $\begin{array}{c}0.199 * * \\
(2.03)\end{array}$ & $\begin{array}{c}-0.126^{* *} \\
(-2.06)\end{array}$ & $\begin{array}{c}0.0636 \\
(1.06)\end{array}$ & $\begin{array}{c}-0.0800 * * \\
(-2.17)\end{array}$ & $\begin{array}{l}0.0261 \\
(0.76)\end{array}$ & $\begin{array}{c}-0.0380 * \\
(-1.86)\end{array}$ & $\begin{array}{c}0.0138 \\
(0.49)\end{array}$ & $\begin{array}{c}0.00587 \\
(0.35)\end{array}$ & $\begin{array}{l}0.0402 \\
(1.48)\end{array}$ & $\begin{array}{l}0.0240 \\
(1.50)\end{array}$ & $\begin{array}{l}0.0202 \\
(0.77)\end{array}$ & $\begin{array}{c}0.0415 * * \\
(2.37)\end{array}$ & $\begin{array}{c}0.00531 \\
(0.19)\end{array}$ & $\begin{array}{c}0.0628^{* * *} \\
(2.83)\end{array}$ & $\begin{array}{l}0.0115 \\
(0.25)\end{array}$ \\
\hline IO, lag & & $\begin{array}{c}-1.423^{* *} \\
(-2.38)\end{array}$ & & $\begin{array}{c}-5.413^{* * *} \\
(-2.93)\end{array}$ & & $\begin{array}{c}-3.972^{* * *} \\
(-3.17)\end{array}$ & & $\begin{array}{c}-1.991 * * * \\
(-2.89)\end{array}$ & & $\begin{array}{l}-0.867 \\
(-1.65)\end{array}$ & & $\begin{array}{l}-0.552 \\
(-1.19)\end{array}$ & & $\begin{array}{l}0.158 \\
(0.35)\end{array}$ & & $\begin{array}{c}0.733^{*} \\
(1.75)\end{array}$ & & $\begin{array}{l}0.989 \\
(1.59)\end{array}$ \\
\hline \multirow[t]{2}{*}{ Hansen(p-val) } & 0.343 & 0.647 & 0.283 & 0.804 & 0.418 & 0.770 & 0.423 & 0.586 & 0.368 & 0.711 & 0.308 & 0.767 & 0.474 & 0.743 & 0.303 & 0.648 & 0.542 & 0.829 \\
\hline & \multicolumn{18}{|c|}{ IO index: occupation between-groups inequality (race \& gender) } \\
\hline Ineq., lag & $\begin{array}{c}-0.0471^{*} \\
(-1.79)\end{array}$ & $\begin{array}{l}-0.0193 \\
(-0.56)\end{array}$ & $\begin{array}{l}-0.0512 \\
(-0.65)\end{array}$ & $\begin{array}{c}0.170^{* *} \\
(2.08)\end{array}$ & $\begin{array}{c}-0.126^{* *} \\
(-2.06)\end{array}$ & $\begin{array}{l}0.0104 \\
(0.17)\end{array}$ & $\begin{array}{c}-0.0800^{* *} \\
(-2.17)\end{array}$ & $\begin{array}{c}-0.0282 \\
(-0.69)\end{array}$ & $\begin{array}{c}-0.0380^{*} \\
(-1.86)\end{array}$ & $\begin{array}{l}-0.0444 \\
(-1.41)\end{array}$ & $\begin{array}{c}0.00587 \\
(0.35)\end{array}$ & $\begin{array}{c}-0.00520 \\
(-0.18)\end{array}$ & $\begin{array}{l}0.0240 \\
(1.50)\end{array}$ & $\begin{array}{c}-0.0119 \\
(-0.45)\end{array}$ & $\begin{array}{c}0.0415^{* *} \\
(2.37)\end{array}$ & $\begin{array}{c}-0.00960 \\
(-0.34)\end{array}$ & $\begin{array}{c}0.0628^{* * *} \\
(2.83)\end{array}$ & $\begin{array}{c}-0.00300 \\
(-0.07)\end{array}$ \\
\hline IO, lag & & $\begin{array}{l}-0.338 \\
(-0.75)\end{array}$ & & $\begin{array}{c}-3.529 * * * \\
(-3.16)\end{array}$ & & $\begin{array}{c}-2.116^{* * *} \\
(-2.70)\end{array}$ & & $\begin{array}{l}-0.716 \\
(-1.43)\end{array}$ & & $\begin{array}{l}0.195 \\
(0.46)\end{array}$ & & $\begin{array}{l}0.314 \\
(0.74)\end{array}$ & & $\begin{array}{c}0.736^{*} \\
(1.86)\end{array}$ & & $\begin{array}{c}0.959 * * \\
(2.43)\end{array}$ & & $\begin{array}{c}1.140^{* *} \\
(2.18)\end{array}$ \\
\hline \multirow[t]{2}{*}{ Hansen(p-val) } & 0.343 & 0.644 & 0.283 & 0.778 & 0.418 & 0.722 & 0.423 & 0.721 & 0.368 & 0.678 & 0.308 & 0.685 & 0.474 & 0.689 & 0.303 & 0.711 & 0.542 & 0.832 \\
\hline & \multicolumn{18}{|c|}{ IO index: Occupational mobility index } \\
\hline & $\begin{array}{c}-0.0471 * \\
(-1.79)\end{array}$ & $\begin{array}{c}0.0343 \\
(1.02)\end{array}$ & $\begin{array}{l}-0.0512 \\
(-0.65)\end{array}$ & $\begin{array}{l}0.127 \\
(1.20)\end{array}$ & $\begin{array}{c}-0.126^{* *} \\
(-2.06)\end{array}$ & $\begin{array}{c}0.0396 \\
(0.55)\end{array}$ & $\begin{array}{c}-0.0800^{* *} \\
(-2.17)\end{array}$ & $\begin{array}{c}0.0272 \\
(0.70)\end{array}$ & $\begin{array}{c}-0.0380 * \\
(-1.86)\end{array}$ & $\begin{array}{c}0.0244 \\
(0.87)\end{array}$ & $\begin{array}{c}0.00587 \\
(0.35)\end{array}$ & $\begin{array}{l}0.0427 \\
(1.47)\end{array}$ & $\begin{array}{l}0.0240 \\
(1.50)\end{array}$ & $\begin{array}{c}0.0499 * \\
(1.95)\end{array}$ & $\begin{array}{c}0.0415^{* *} \\
(2.37)\end{array}$ & $\begin{array}{c}0.0664^{* *} \\
(2.46)\end{array}$ & $\begin{array}{c}0.0628^{* * *} \\
(2.83)\end{array}$ & $\begin{array}{c}0.0880^{* *} \\
(2.39)\end{array}$ \\
\hline IO, lag & & $\begin{array}{c}-0.0413^{* *} \\
(-2.19)\end{array}$ & & $\begin{array}{c}-0.131^{* * *} \\
(-2.85)\end{array}$ & & $\begin{array}{c}-0.0981^{* * *} \\
(-2.96)\end{array}$ & & $\begin{array}{c}-0.0505^{* *} \\
(-2.50)\end{array}$ & & $\begin{array}{l}-0.0255 \\
(-1.56)\end{array}$ & & $\begin{array}{l}-0.0182 \\
(-1.13)\end{array}$ & & $\begin{array}{l}-0.0127 \\
(-0.93)\end{array}$ & & $\begin{array}{l}-0.0132 \\
(-0.99)\end{array}$ & & $\begin{array}{l}-0.0145 \\
(-0.95)\end{array}$ \\
\hline Hansen(p-val) & 0.343 & 0.737 & 0.283 & 0.738 & 0.418 & 0.767 & 0.423 & 0.709 & 0.368 & 0.701 & 0.308 & 0.759 & 0.474 & 0.797 & 0.303 & 0.629 & 0.542 & 0.920 \\
\hline Num. Obs & 240 & 240 & 240 & 240 & 240 & 240 & 240 & 240 & 240 & 240 & 240 & 240 & 240 & 240 & 240 & 240 & 240 & 240 \\
\hline Num. states & 48 & 48 & 48 & 48 & 48 & 48 & 48 & 48 & 48 & 48 & 48 & 48 & 48 & 48 & 48 & 48 & 48 & 48 \\
\hline Num. Instr. & 53 & 61 & 53 & 61 & 53 & 61 & 53 & 61 & 53 & 61 & 53 & 61 & 53 & 61 & 53 & 61 & 53 & 61 \\
\hline
\end{tabular}

See Note in Table 3. 
Table 5. Income growth and inequality by percentiles in the U.S.: estimated results using robust System-GMM (Collapse instruments)

(extended controls from Marrero and Rodríguez, 2013)

\begin{tabular}{|c|c|c|c|c|c|c|c|c|c|c|c|c|c|c|c|c|c|c|}
\hline \multirow[b]{2}{*}{ Ineq., lag } & \multicolumn{2}{|c|}{ All sample } & \multicolumn{2}{|c|}{ Percentile 05} & \multicolumn{2}{|c|}{ Percentile 10} & \multicolumn{2}{|c|}{ Percentile 25} & \multicolumn{2}{|c|}{ Percentile 50} & \multicolumn{2}{|c|}{ Percentile 75} & \multicolumn{2}{|c|}{ Percentile 90 } & \multicolumn{2}{|c|}{ Percentile 95} & \multicolumn{2}{|c|}{ Percentile 99} \\
\hline & $\begin{array}{c}0.00956 \\
(0.41)\end{array}$ & $\begin{array}{l}0.0283 \\
(1.13)\end{array}$ & $\begin{array}{l}0.0634 \\
(0.98)\end{array}$ & $\begin{array}{c}0.157^{* *} \\
(2.35)\end{array}$ & $\begin{array}{l}-0.0125 \\
(-0.28)\end{array}$ & $\begin{array}{l}0.0331 \\
(0.74)\end{array}$ & $\begin{array}{l}-0.0114 \\
(-0.40)\end{array}$ & $\begin{array}{c}0.00388 \\
(0.14)\end{array}$ & $\begin{array}{c}0.00373 \\
(0.18)\end{array}$ & 0.00774 & 0.0250 & $\begin{array}{l}0.0121 \\
0.58)\end{array}$ & $0.0303^{* *}$ & 0.00402 & $0.0371 * *$ & -0.000633 & $0.0441^{* *}$ & -0.0367 \\
\hline \multirow[t]{2}{*}{ IO, lag } & & -0.0815 & & $-0.488^{* * *}$ & & $-0.226^{*}$ & & -0.0709 & & -0.0353 & & 0.0225 & & 0.0600 & & 0.0902 & & $0.205^{* *}$ \\
\hline & & $(-1.20)$ & & $(-3.40)$ & & $(-1.87)$ & & $(-0.90)$ & & $(-0.54)$ & & $(0.39)$ & & (1.01) & & (1.43) & & (2.54) \\
\hline \multirow[t]{2}{*}{$\ln (y), \operatorname{lag}$} & $-0.0456 * * *$ & $-0.0482^{* * * *}$ & $-0.0402 * * *$ & $-0.0497 * * *$ & $-0.0475^{* * *}$ & $-0.0526^{* * *}$ & $-0.0460 * * *$ & $-0.0482^{* * *}$ & * $-0.0503^{* * *}$ & $*-0.0523 * * *$ & $-0.0409 * * *$ & $-0.0414 * * *$ & * $-0.0375 * * *$ & $-0.0377 * * *$ & $-0.0303 * * *$ & $-0.0301 * * *$ & $-0.0367 * * *$ & $-0.0371^{* * *}$ \\
\hline & $(-6.17)$ & $(-6.40)$ & $(-4.59)$ & $(-6.12)$ & $(-7.12)$ & $(-7.42)$ & $(-7.85)$ & $(-7.44)$ & $(-6.16)$ & $(-6.73)$ & $(-4.57)$ & $(-4.90)$ & $(-4.51)$ & $(-4.84)$ & $(-3.84)$ & $(-3.85)$ & $(-3.70)$ & $(-3.82)$ \\
\hline \multirow[t]{2}{*}{ Edu_ms, lag } & 0.0472 & $0.0552^{*}$ & 0.00727 & 0.0266 & 0.0375 & 0.0488 & 0.0465 & $0.0537 * *$ & $0.0567 *$ & $0.0663 * *$ & 0.0431 & $0.0506^{*}$ & 0.0328 & 0.0415 & 0.0222 & 0.0317 & 0.0317 & 0.0485 \\
\hline & $(1.50)$ & $(1.90)$ & $(0.12)$ & $(0.50)$ & $(0.82)$ & $(1.17)$ & $(1.65)$ & $(2.07)$ & $(1.87)$ & $(2.42)$ & (1.52) & $(1.90)$ & $(1.22)$ & (1.59) & $(0.87)$ & $(1.24)$ & (1.04) & (1.53) \\
\hline \multirow[t]{2}{*}{ OLM-fem., lag } & $-0.0561^{* *}$ & $-0.0549 * *$ & $-0.108^{* *}$ & $-0.122^{* *}$ & $-0.0976 * *$ & $-0.100 * * *$ & $-0.0675 * * *$ & $-0.0656^{* * *}$ & * $-0.0566 * *$ & $-0.0509 * * *$ & $-0.0384^{*}$ & -0.0300 & $-0.0409 * *$ & -0.0278 & $-0.0491 * * *$ & $-0.0315^{*}$ & -0.0190 & 0.0120 \\
\hline & $(-2.42)$ & $(-2.53)$ & $(-2.07)$ & $(-2.53)$ & $(-2.64)$ & $(-2.79)$ & $(-2.78)$ & $(-2.89)$ & $(-2.64)$ & $(-2.71)$ & $(-1.82)$ & $(-1.56)$ & $(-2.03)$ & $(-1.48)$ & $(-2.76)$ & $(-1.80)$ & $(-0.62)$ & $(0.37)$ \\
\hline \multirow[t]{2}{*}{ Age 0-15, lag } & -0.0857 & -0.0959 & -0.141 & -0.192 & -0.100 & -0.126 & -0.000933 & -0.0106 & -0.0747 & -0.0809 & -0.0714 & -0.0709 & $-0.176^{* * * *}$ & $-0.177 * * *$ & $-0.203 * * *$ & $-0.203^{* * *}$ & -0.129 & -0.126 \\
\hline & $(-1.11)$ & $(-1.35)$ & $(-0.96)$ & $(-1.39)$ & $(-0.85)$ & $(-1.14)$ & $(-0.01)$ & $(-0.14)$ & $(-1.06)$ & $(-1.25)$ & $(-1.11)$ & $(-1.19)$ & $(-2.69)$ & $(-2.86)$ & $(-3.15)$ & $(-3.35)$ & $(-1.62)$ & $(-1.66)$ \\
\hline \multirow[t]{2}{*}{ Age 65+, lag } & -0.0767 & -0.0838 & -0.0374 & -0.112 & -0.0620 & -0.0935 & -0.0165 & -0.0181 & -0.0815 & -0.0792 & -0.0743 & -0.0712 & $-0.133^{* *}$ & $-0.125 * *$ & $-0.145^{* *}$ & $-0.135 * *$ & -0.0680 & -0.0360 \\
\hline & $(-1.30)$ & $(-1.45)$ & $(-0.27)$ & $(-0.82)$ & $(-0.59)$ & $(-0.88)$ & $(-0.27)$ & $(-0.30)$ & $(-1.55)$ & $(-1.61)$ & $(-1.45)$ & $(-1.46)$ & $(-2.26)$ & $(-2.16)$ & $(-2.44)$ & $(-2.30)$ & $(-1.14)$ & $(-0.65)$ \\
\hline \multirow[t]{2}{*}{ Emp_cons, lag } & -0.0999 & -0.0961 & $-0.336^{*}$ & -0.295 & $-0.240 * *$ & $-0.215^{*}$ & -0.0753 & -0.0709 & -0.0736 & -0.0790 & -0.0615 & -0.0715 & 0.0000836 & -0.0191 & 0.0364 & 0.0108 & 0.00801 & -0.0527 \\
\hline & $(-1.43)$ & $(-1.35)$ & $(-1.89)$ & $(-1.63)$ & $(-2.14)$ & $(-1.87)$ & $(-1.01)$ & $(-0.95)$ & $(-1.23)$ & $(-1.35)$ & $(-1.03)$ & $(-1.20)$ & $(0.00)$ & $(-0.35)$ & $(0.65)$ & $(0.19)$ & $(0.11)$ & $(-0.67)$ \\
\hline \multirow[t]{2}{*}{ Emp_finan., lag } & 0.0730 & 0.0564 & -0.0335 & -0.0369 & -0.0192 & -0.0155 & 0.0498 & 0.0358 & $0.105^{*}$ & 0.0772 & 0.0929 & 0.0745 & 0.115 & 0.0960 & 0.116 & 0.101 & 0.183 & 0.155 \\
\hline & (1.11) & $(0.94)$ & $(-0.25)$ & $(-0.27)$ & $(-0.19)$ & $(-0.16)$ & $(0.71)$ & $(0.53)$ & (1.76) & (1.46) & (1.51) & $(1.20)$ & (1.60) & (1.25) & (1.19) & $(0.94)$ & (1.35) & $(0.96)$ \\
\hline \multirow[t]{2}{*}{ Emp_gov, lag } & $0.0728^{* *}$ & $0.0639 *$ & $0.169^{* * *}$ & $0.133^{*}$ & $0.122^{* * *}$ & $0.104^{* *}$ & $0.0668^{* *}$ & 0.0593 & $0.0603^{* *}$ & $0.0534^{*}$ & $0.0578^{* *}$ & $0.0568^{*}$ & $0.0605^{* *}$ & $0.0644^{* *}$ & $0.0547 * *$ & $0.0617^{* *}$ & 0.0316 & 0.0428 \\
\hline & $(2.31)$ & $(1.84)$ & $(2.78)$ & (1.95) & $(2.70)$ & $(2.08)$ & $(2.04)$ & (1.64) & $(2.16)$ & (1.76) & $(2.10)$ & $(1.97)$ & $(2.27)$ & $(2.37)$ & $(2.35)$ & $(2.66)$ & $(0.90)$ & $(1.30)$ \\
\hline \multirow[t]{2}{*}{ Emp_growth, lag } & -0.00704 & -0.00569 & -0.0167 & -0.0137 & -0.0107 & -0.00987 & -0.00693 & -0.00577 & -0.00627 & -0.00440 & -0.00317 & -0.00188 & -0.00587 & -0.00398 & -0.00673 & -0.00454 & -0.00466 & -0.000258 \\
\hline & $(-1.38)$ & $(-1.07)$ & $(-1.48)$ & $(-1.19)$ & $(-1.28)$ & $(-1.20)$ & $(-1.24)$ & $(-1.03)$ & $(-1.29)$ & $(-0.92)$ & $(-0.76)$ & $(-0.44)$ & $(-1.40)$ & $(-0.93)$ & $(-1.64)$ & $(-1.12)$ & $(-0.87)$ & $(-0.05)$ \\
\hline \multirow[t]{2}{*}{ Fertility, lag } & $-0.0357 * * *$ & $-0.0370 * * *$ & -0.0222 & -0.0250 & $-0.0335 * *$ & $-0.0352^{* *}$ & $-0.0516^{* * *}$ & $-0.0529 * * *$ & $*-0.0404 * * *$ & $*-0.0419 * * *$ & $-0.0399 * * *$ & $-0.0409 * * *$ & $-0.0252^{* * *}$ & $-0.0263 * * *$ & $-0.0183^{* * *}$ & $-0.0195 * * *$ & $-0.0263^{* *}$ & $-0.0268^{* *}$ \\
\hline & $(-3.74)$ & $(-3.80)$ & $(-1.23)$ & $(-1.39)$ & $(-2.22)$ & $(-2.31)$ & $(-4.94)$ & $(-4.96)$ & $(-4.33)$ & $(-4.46)$ & $(-4.77)$ & $(-4.90)$ & $(-3.34)$ & $(-3.51)$ & $(-2.74)$ & $(-3.07)$ & $(-2.13)$ & $(-2.38)$ \\
\hline \multirow[t]{2}{*}{ Welfare, lag } & -0.0849 & -0.119 & 0.0723 & -0.0317 & -0.106 & -0.156 & -0.0823 & -0.110 & -0.101 & -0.132 & -0.113 & -0.126 & -0.105 & -0.119 & -0.0630 & -0.0686 & $-0.252^{* *}$ & $-0.243^{* *}$ \\
\hline & $(-0.81)$ & $(-1.14)$ & $(0.29)$ & $(-0.13)$ & $(-0.60)$ & $(-0.89)$ & $(-0.75)$ & $(-0.99)$ & $(-1.03)$ & $(-1.34)$ & $(-1.32)$ & $(-1.52)$ & $(-1.26)$ & $(-1.53)$ & $(-0.79)$ & $(-0.92)$ & $(-2.62)$ & $(-2.53)$ \\
\hline Num.Obs. & 240 & 240 & 240 & 240 & 240 & 240 & 240 & 240 & 240 & 240 & 240 & 240 & 240 & 240 & 240 & 240 & 240 & 240 \\
\hline hansen (p-val) & 0.595 & 0.795 & 0.730 & 0.920 & 0.638 & 0.884 & 0.560 & 0.832 & 0.560 & 0.797 & 0.678 & 0.825 & 0.665 & 0.815 & 0.713 & 0.834 & 0.772 & 0.842 \\
\hline m1(p-val) & 0.0000113 & 0.0000210 & 0.0000823 & 0.0000934 & 0.0000123 & 0.0000147 & 0.0000239 & 0.0000326 & 0.00000999 & 90.0000193 & 0.0000243 & 0.0000388 & 0.0000375 & 0.0000504 & 0.0000140 & 0.0000189 & 0.0000657 & 0.000109 \\
\hline m2(p-val) & 0.151 & 0.272 & 0.113 & 0.210 & 0.0824 & 0.149 & 0.128 & 0.218 & 0.167 & 0.249 & 0.609 & 0.621 & 0.572 & 0.511 & 0.877 & 0.985 & 0.435 & 0.358 \\
\hline AR(3)(p-val) & 0.0684 & 0.0551 & 0.270 & 0.214 & 0.0400 & 0.0546 & 0.0177 & 0.0182 & 0.0533 & 0.0566 & 0.229 & 0.254 & 0.468 & 0.656 & 0.329 & 0.491 & 1.000 & 0.553 \\
\hline Num.Stat & 48 & 48 & 48 & 48 & 48 & 48 & 48 & 48 & 48 & 48 & 48 & 48 & 48 & 48 & 48 & 48 & 48 & 48 \\
\hline Num.Instr. & 65 & 70 & 65 & 70 & 65 & 70 & 65 & 70 & 65 & 70 & 65 & 70 & 65 & 70 & 65 & 70 & 65 & 70 \\
\hline
\end{tabular}

See Note in Table 3. System-GMM is estimated collapsing the matrix of instruments to avoid the problem of 'too-many instruments' (Roodman, 2009a). 


\section{References}

Acemoglu, D., Naidu S., Restrepo, P. and J.A. Robinson (2015), "Democracy, redistribution and inequality" in Handbook of Income Distribution, Vol. 2B (Ch. 21), A. Atkinson and F. Bourguignon (Eds.), North-Holland: Elsevier.

Arellano, M. and Bond, S. (1991), "Some Tests of Specification for Panel Data: Monte Carlo Evidence and an Application to Employment Equations", Review of Economic Studies, 58, 277-297.

Arellano, M. and O. Bover (1995), “Another look at the instrumental-variable estimation of error-components models”, Journal of Econometrics, 68, 29-52.

Atkinson, A. B. (1970), "On the measurement of inequality", Journal of Economic Theory, 2, 244-263.

Banerjee, A. and Duflo, E. (2003), "Inequality and growth: what can the data say?", Journal of Economic Growth, 8, 267-299.

Barro, R.J. (2000), "Inequality and Growth in a Panel of Countries", Journal of Economic Growth, 5, 5-32.

Bertrand, M. and Mullainathan, S. (2004), "Are Emily and Greg more employable than Lakisha and Jamal? A field experiment on labor market discrimination", American Economic Review, 94, 991-1013

Blundell, R. and S. Bond (1998), "Initial Conditions and Moment Restrictions in Dynamic Panel Data Models”, Journal of Econometrics 87, 115-143.

Bond, S., Hoeffler, A. and J. Temple (2001), "GMM Estimation of Empirical Growth Models”, Economics Papers 2001-W2 1, Economics Group, Nuffield College, University of Oxford.

Bourguignon, F. (1979), "Decomposable income inequality measures”, Econometrica, 47, 901-920.

Bourguignon, F., Ferreira, F. and Menéndez, M. (2007), "Inequality of opportunity in Brazil”, Review of Income and Wealth, 53, 585-618.

Bowles, S., Gintis, H. and Osborne-Groves, M. (2005), Unequal chance: family background and economic success, Russell Sage Foundation and Princeton University Press, New York.

Calo-Blanco, A. and García-Pérez, J. I. (2014), “On the welfare loss caused by inequality of opportunity”, Journal of Economic Inequality, 12, 221-237.

Castelló-Climent, A. and Mukhopadhyay, A. (2013), "Mass education or a minority well educated elite in the process of growth: The case of India", Journal of Development Economics, 105, pp. 303-320.

Ferreira, F. and Gignoux, J. (2011), "The measurement of inequality of opportunity: theory and an application to Latin America", Review of Income and Wealth, 57, 622-657. 
Fleurbaey, M. (2008), Fairness, responsibility, and welfare, Oxford: Oxford University Press.

Foster, J. and Shneyerov, A. (2000), “Path independent inequality measures”, Journal of Economic Theory, 91, 199-222.

Galor, O. and Moav, O. (2004), "From Physical to Human Capital Accumulation: Inequality and the Process of Development", Review of Economic Studies, 71, 1001-1026.

Hederos, K., Jäntti, M. and Lindahl, L. (2014), “Gender and inequality of opportunity in Sweden”, mimeo.

Krueger, A. (2012): “The Rise and Consequences of Inequality”, Presentation made to the Center for American Progress, January 12th. Available at http://www.americanprogress.org/events//2012/01/12/17181/the-rise-and-consequencesof-inequality/

Lang, K. and Manove, M. (2011), "Education and labor market discrimination”, American Economic Review, 101, 1467-1496

Lefranc, A., Pistolesi, N. and Trannoy A. (2008), "Inequality of opportunities vs. inequality of outcomes: Are Western societies all alike?”, Review of Income and Wealth, 54, 513-546.

Mankiw, N. G. (2013), "Defending the one percent", Journal of Economic Perspectives, 27, 21-34.

Marrero, G.A. and J.G. Rodríguez (2011), "Inequality of Opportunity in the U.S.: trends and decomposition", Research on Economic Inequality, 19, 217-46.

Marrero, G.A. and Rodríguez, J.G. (2012), "Inequality of opportunity in Europe", Review of Income and Wealth, 58, 597-621.

Marrero, G.A. and Rodríguez, J.G. (2013), "Inequality of opportunity and growth", Journal of Development Economics, 104, 107-122.

Marrero, A.G. and Rodríguez, J.G. (2016a), "Inequality ... of opportunity and economic performance", Economic Review of the Federal Reserve Bank of St. Louis, forthcoming.

Marrero, G.A. and Rodríguez, J.G. (2016b), "Macroeconomic determinants of inequality of opportunity and effort in the US: 1970-2009", Research on Economic Inequality, forthcoming.

Panizza, U. (2002), "Income inequality and economic growth: evidence from American data”, Journal of Economic Growth, 7, 25-41.

Rodríguez, J.G. (2008), "Partial equality-of-opportunity orderings", Social Choice and Welfare, 31, 435-456.

Roemer, J.E. (1993), "A pragmatic approach to responsibility for the egalitarian planner", Philosophy \& Public Affairs, 20, 146-166.

Roemer, J.E. (1998), Equality of opportunity, Cambridge, MA: Harvard University Press. 
Roemer, J. E., Aaberge, R., Colombino, U., Fritzell, J., Jenkins, S., Marx, I., Page, M., Pommer, E., Ruiz-Castillo, J., San Segundo, M. J., Tranaes, T., Wagner, G. and Zubiri, I. (2003), "To what extent do fiscal regimes equalize opportunities for income acquisition among citizens?”, Journal of Public Economics, 87, 539-565.

Roodman, D. (2009a), “A note on the theme of too many instruments”, Oxford Bulletin of Economics and Statistics, 71, 135-158.

Roodman, D. (2009b), “How to do xtabond2: an introduction to 'difference' and 'system' GMM in Stata”, The Stata Journal, 9, 86-136.

Shorrocks, A. F. (1980), “The class of additively decomposable inequality measures”, Econometrica, 48, 613-625.

Van de Gaer, D. (1993), "Equality of opportunity and investment in human capital", Catholic University of Leuven, Faculty of Economics, no. 92.

van der Weide, R. and B. Milanovic (2014), "Inequality is bad for growth of the poor (but not for that of the rich)", Policy Research Working Paper Series 6963, The World Bank.

Voitchovsky, S. (2005), "Does the profile of income inequality matter for economic growth?: distinguishing between the effects of inequality in different parts of the income distribution", Journal of Economic Growth, 10, 273-296.

Windmeijer F. (2005), “A finite sample correction for the variance of linear efficient twostep GMM estimators”, Journal of Econometrics, 126, 25-51. 


\section{Annex A: Visual inspection of main results for pooled-OLS}

For a selection of income quantiles (5th representing the poor, 50th representing the middle class and 95th representing the rich), we show in Figure A1 the scatter plots between income growth, overall inequality as well as IO. Both income growth and the inequality variables are adjusted for time and regional dummies plus the set of controls used in Section 4.2.

The first row examines the partial relationship between growth and lagged total inequality when the IO variable is not controlled for: the slope is negative for the poor and positive for the rich, while it is insignificant for the middle class. The second row shows the partial correlation between growth and total inequality but now controlling for IO. Once the IO component is included in the model, total inequality turns insignificant to explain income growth along the income distribution. More importantly, the third row of plots shows the partial correlations between growth and IO in this amplified model. Comparing the first with the third row leads us to conclude that much of the relationship between inequality and growth along the income distribution is due to IO. 
Figure A1. The effects of overall inequality and inequality of opportunity on growth. $\left(5^{\text {th }}, 50^{\text {th }}\right.$ and $95^{\text {th }}$ percentiles)

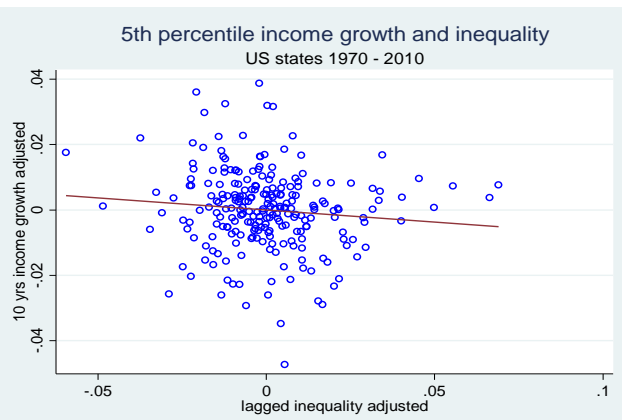

5th percentile income growth and inequality -including 10

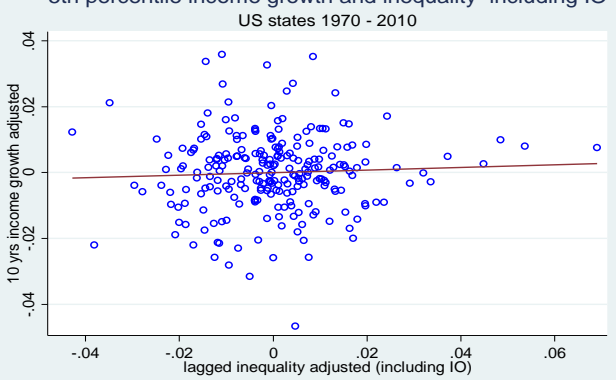

5 th percentile income growth and 10 -including inequality

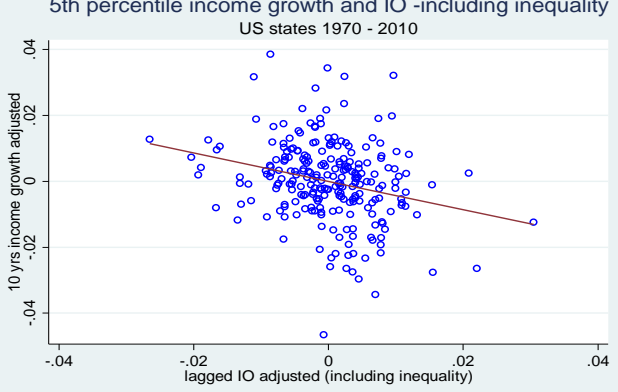

50th percentile income growth and inequality

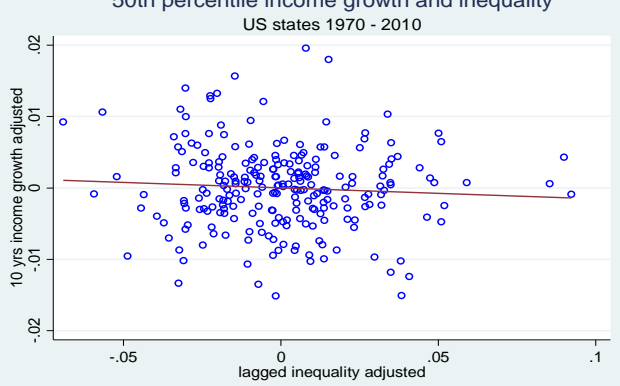

50th percentile income growth and inequality -including IO

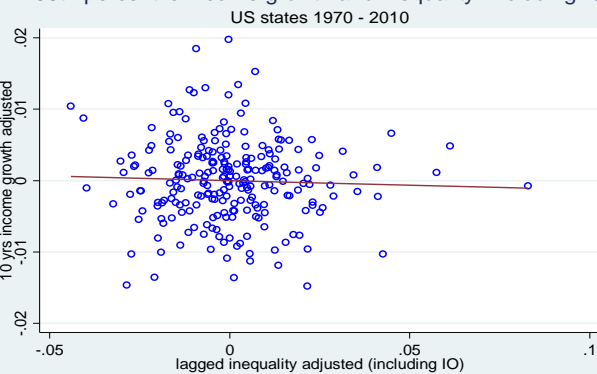

50th percentile income growth and 10 -including inequality

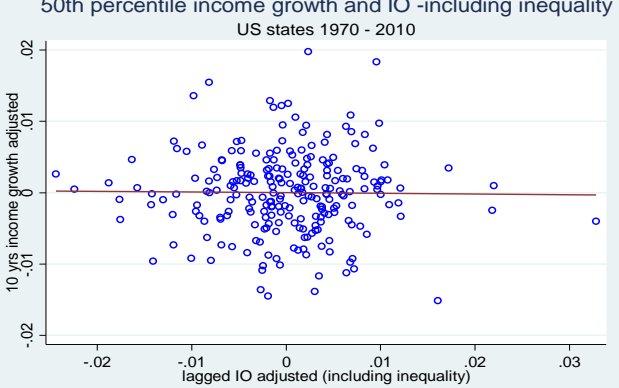

95th percentile income growth and inequality

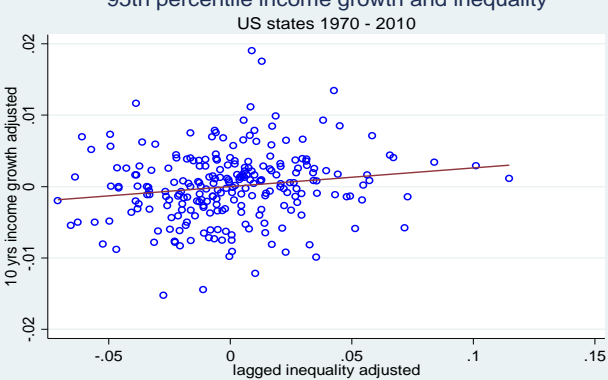

95th percentile income growth and inequality -including 10

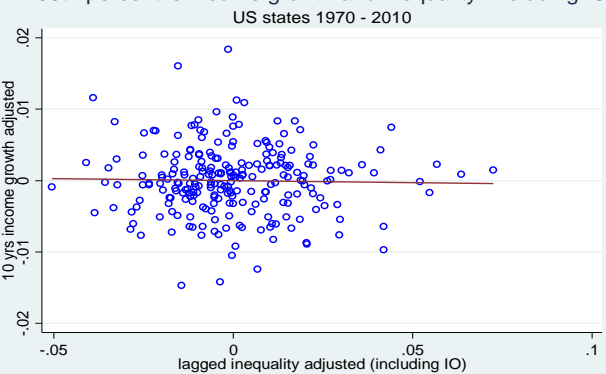

95th percentile income growth and 10 -including inequality

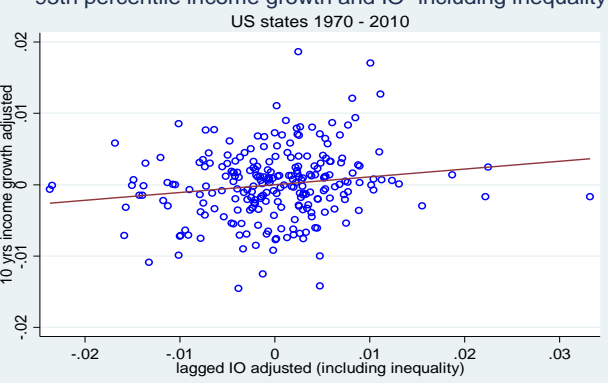




\section{Annex B: Alternative System-GMM specifications}

To test the robustness of our results, we also consider alternative GMM specifications (see Table B1). The first panel shows estimation results using the firstdifference GMM approach (Arellano and Bond, 1991), considering the same lagged structure than for the baseline System-GMM specification described above. A two-step System-GMM (also using the 2 lags structure) denotes our second robustness check. Next, we specify three alternative approaches that reduce the number of instruments. We reduce the instrument count for the one-step System-GMM to just one lag ( $t-3$ for the first-difference equations and $t$-2 for the level equations); second, we consider all lags but collapse the matrix of instruments (Roodman, 2009a); third, we use Principal Components Analysis to reduce the matrix of instruments (Roodman, 2009b). As it is shown in the Table, the over identifying Hansen J-test fails many times under these specifications, being this one of the reasons for which we have used the one-step SystemGMM including 2 lags in the matrix of instruments as our preferred approach for the baseline specification (using one or two steps leads to similar results).

The results obtained with these alternative System-GMM specifications are similar to the findings of the previous subsection 4.3, although, the effect of inequality of opportunity on growth of the rich is not significant for some of the new specifications. We can say, therefore, that the effect of IO on the growth of low incomes is more powerful than the one on the growth of high incomes since the former is more robust. 
Table B1. Income growth and inequality by percentiles in the U.S.: estimated results using alternative GMM estimates.

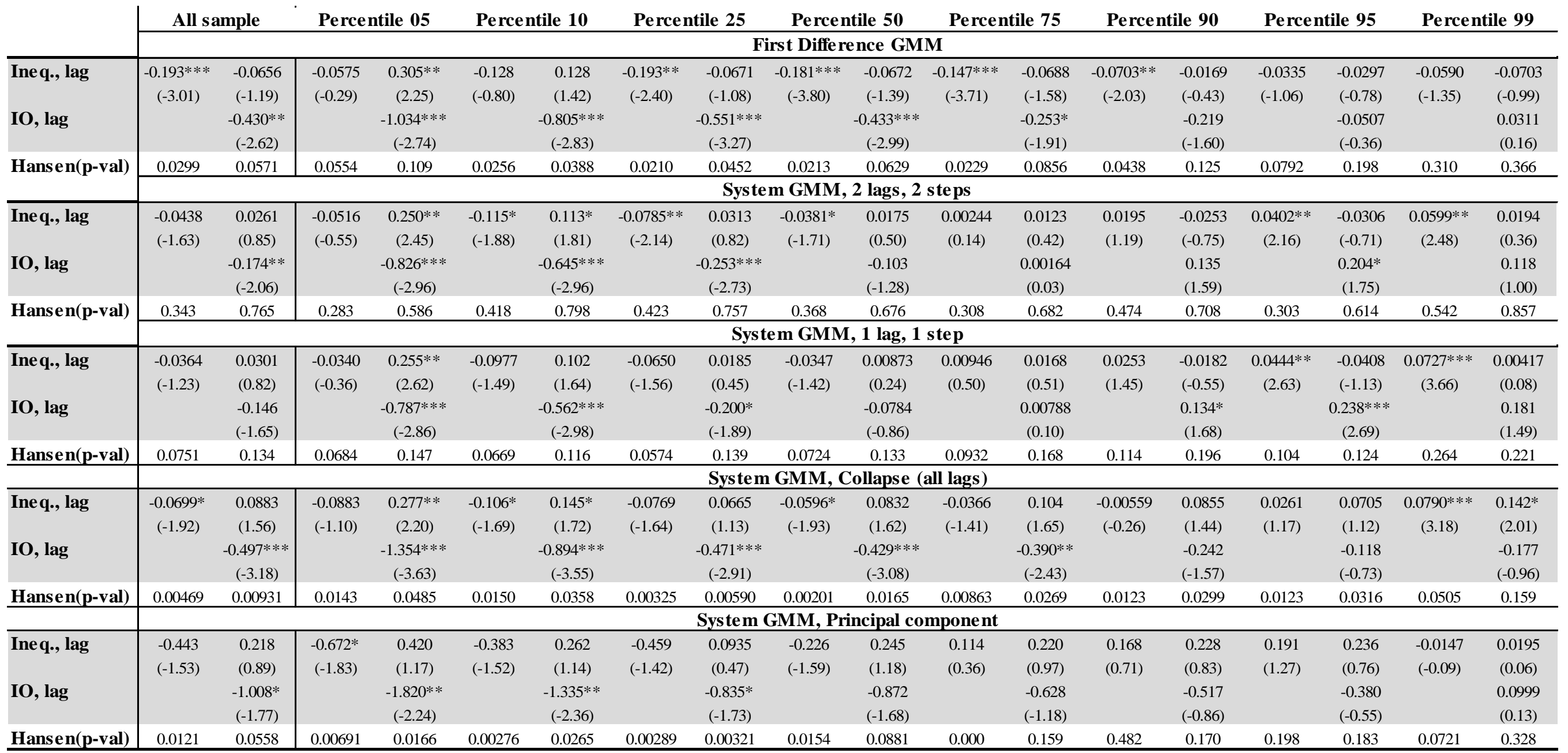

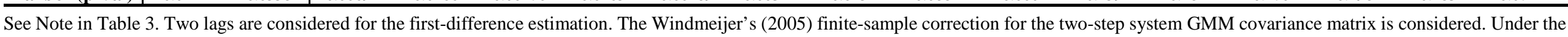
collapse and principal component options, the number of instruments finally included is small, which produces low $p$-values for the Hansen test. 
Table B2. Income growth and inequality by percentiles in the U.S.: estimated results using robust System-GMM (Collapse instruments) (extended controls from Marrero and Rodríguez, 2013, excluding OLF-FEM from Table 5)

\begin{tabular}{|c|c|c|c|c|c|c|c|c|c|c|c|c|c|c|c|c|c|c|}
\hline \multirow[b]{2}{*}{ Ineq., lag } & \multicolumn{2}{|c|}{ All sample } & \multicolumn{2}{|c|}{ Percentile 05 } & \multicolumn{2}{|c|}{ Percentile 10} & \multicolumn{2}{|c|}{ Percentile 25} & \multicolumn{2}{|c|}{ Percentile 50} & \multicolumn{2}{|c|}{ Percentile 75} & \multicolumn{2}{|c|}{ Percentile 90} & \multicolumn{2}{|c|}{ Percentile 95} & \multicolumn{2}{|c|}{ Percentile 99 } \\
\hline & $\begin{array}{c}-0.0375 * \\
(-1.71)\end{array}$ & $\begin{array}{l}-0.0315 \\
(-1.03)\end{array}$ & $\begin{array}{l}-0.0650 \\
(-0.89)\end{array}$ & $\begin{array}{l}-0.0156 \\
(-0.19)\end{array}$ & $\begin{array}{c}-0.119 * * \\
(-2.40)\end{array}$ & $\begin{array}{c}-0.0967^{*} \\
(-1.75)\end{array}$ & $\begin{array}{c}-0.0746 * * \\
(-2.52)\end{array}$ & $\begin{array}{c}-0.0702^{*} \\
(-1.93)\end{array}$ & $\begin{array}{c}-0.0385^{*} \\
(-1.96)\end{array}$ & $\begin{array}{l}-0.0444 \\
(-1.59)\end{array}$ & $\begin{array}{c}0.00123 \\
(0.08)\end{array}$ & $\begin{array}{l}-0.0145 \\
(-0.61)\end{array}$ & $\begin{array}{l}0.0126 \\
(0.91)\end{array}$ & $\begin{array}{l}-0.0149 \\
(-0.66)\end{array}$ & $\begin{array}{c}0.0251^{*} \\
(1.77)\end{array}$ & $\begin{array}{l}-0.0150 \\
(-0.75)\end{array}$ & $\begin{array}{c}0.0391 * * \\
(2.17)\end{array}$ & $\begin{array}{l}-0.0265 \\
(-0.79)\end{array}$ \\
\hline IO, lag & & $\begin{array}{l}-0.0182 \\
(-0.22)\end{array}$ & & $\begin{array}{l}-0.328^{*} \\
(-1.92)\end{array}$ & & $\begin{array}{l}-0.103 \\
(-0.75)\end{array}$ & & $\begin{array}{c}0.00489 \\
(0.05)\end{array}$ & & $\begin{array}{l}0.0256 \\
(0.35)\end{array}$ & & $\begin{array}{l}0.0543 \\
(0.86)\end{array}$ & & $\begin{array}{l}0.0873 \\
(1.44)\end{array}$ & & $\begin{array}{c}0.117^{* *} \\
(2.02)\end{array}$ & & $\begin{array}{c}0.184^{* *} \\
(2.50)\end{array}$ \\
\hline $\ln (y), \operatorname{lag}$ & $\begin{array}{c}-0.0565^{* * *} \\
(-9.08)\end{array}$ & $\begin{array}{c}-0.0569 * * * \\
(-8.51)\end{array}$ & $\begin{array}{c}-0.0541^{* * *} \\
(-5.83)\end{array}$ & $\begin{array}{c}-0.0618^{* * *} \\
(-7.40)\end{array}$ & $\begin{array}{c}-0.0605^{* * * *} \\
(-8.99)\end{array}$ & $\begin{array}{c}-0.0632^{* * *} \\
(-8.61)\end{array}$ & $\begin{array}{c}-0.0574 * * * \\
(-10.13)\end{array}$ & $\begin{array}{c}=-0.0564 * * * \\
\quad(-9.14)\end{array}$ & $\begin{array}{c}*-0.0618^{* * *}- \\
\quad(-9.08)\end{array}$ & $\begin{array}{c}-0.0606^{* * * *} \\
(-8.59)\end{array}$ & $\begin{array}{c}-0.0497 * * * \\
(-7.05)\end{array}$ & $\begin{array}{c}-0.0477 * * * \\
(-6.69)\end{array}$ & $\begin{array}{c}-0.0465^{* * *} \\
(-6.49)\end{array}$ & $\begin{array}{c}-0.0439 * * * \\
(-6.27)\end{array}$ & $*-0.0401 * * *$ & $\begin{array}{c}*-0.0363^{* * *} \\
(-5.10)\end{array}$ & $-0.0391 * * *$ & $\begin{aligned}- & -0.0350^{* * * *} \\
& (-4.70)\end{aligned}$ \\
\hline Edu_ms, lag & $\begin{array}{c}0.0955 * * * \\
(3.74)\end{array}$ & $\begin{array}{c}0.0975 * * * \\
(3.97)\end{array}$ & $\begin{array}{c}0.0975^{*} \\
(1.81)\end{array}$ & $\begin{array}{c}0.119^{* *} \\
(2.35)\end{array}$ & $\begin{array}{c}0.118^{* * *} \\
(3.18)\end{array}$ & $\begin{array}{c}0.125 * * * \\
(3.59)\end{array}$ & $\begin{array}{c}0.102 * * * \\
(3.96)\end{array}$ & $\begin{array}{c}0.102^{* * *} \\
(4.32)\end{array}$ & $\begin{array}{c}0.105^{* * *} \\
(4.44)\end{array}$ & $\begin{array}{c}0.105^{* * *} \\
(4.61)\end{array}$ & $\begin{array}{c}0.0787^{* * *} \\
(3.55)\end{array}$ & $\begin{array}{c}0.0761^{* * *} \\
(3.60)\end{array}$ & $\begin{array}{c}0.0712 * * * \\
(3.20)\end{array}$ & $\begin{array}{c}0.0667^{* * *} \\
(3.23)\end{array}$ & $\begin{array}{c}=0.0667 * * * \\
(2.90)\end{array}$ & $\begin{array}{c}0.0594 * * * \\
(2.74)\end{array}$ & $\begin{array}{c}0.0508^{*} \\
(1.93)\end{array}$ & $\begin{array}{l}0.0452 \\
(1.59)\end{array}$ \\
\hline Age 0-15, lag & $\begin{array}{l}-0.0805 \\
(-1.10)\end{array}$ & $\begin{array}{l}-0.0785 \\
(-1.14)\end{array}$ & $\begin{array}{l}-0.113 \\
(-0.81)\end{array}$ & $\begin{array}{l}-0.128 \\
(-0.99)\end{array}$ & $\begin{array}{l}-0.0743 \\
(-0.65)\end{array}$ & $\begin{array}{c}-0.0794 \\
(-0.74)\end{array}$ & $\begin{array}{c}0.00222 \\
(0.03)\end{array}$ & $\begin{array}{c}0.00817 \\
(0.11)\end{array}$ & $\begin{array}{l}-0.0707 \\
(-1.08)\end{array}$ & $\begin{array}{l}-0.0632 \\
(-1.02)\end{array}$ & $\begin{array}{l}-0.0691 \\
(-1.14)\end{array}$ & $\begin{array}{l}-0.0640 \\
(-1.11)\end{array}$ & $\begin{array}{c}-0.169 * * * \\
(-2.79)\end{array}$ & $\begin{array}{c}-0.166^{* * *} \\
(-2.85)\end{array}$ & $\begin{array}{c}-0.197 * * * \\
(-3.33)\end{array}$ & $\begin{array}{c}-0.194^{* * *} \\
(-3.42)\end{array}$ & $\begin{array}{l}-0.118 \\
(-1.62)\end{array}$ & $\begin{array}{l}-0.114 \\
(-1.56)\end{array}$ \\
\hline Age 65+, lag & $\begin{array}{l}-0.0540 \\
(-0.95)\end{array}$ & $\begin{array}{l}-0.0408 \\
(-0.72)\end{array}$ & $\begin{array}{c}-0.00287 \\
(-0.02)\end{array}$ & $\begin{array}{l}-0.0137 \\
(-0.09) \\
\end{array}$ & $\begin{array}{c}-0.00747 \\
(-0.07)\end{array}$ & $\begin{array}{c}0.00320 \\
(0.03) \\
\end{array}$ & $\begin{array}{c}0.00938 \\
(0.16) \\
\end{array}$ & $\begin{array}{l}0.0290 \\
(0.49) \\
\end{array}$ & $\begin{array}{l}-0.0564 \\
(-1.12)\end{array}$ & $\begin{array}{l}-0.0377 \\
(-0.77)\end{array}$ & $\begin{array}{l}-0.0541 \\
(-1.10) \\
\end{array}$ & $\begin{array}{l}-0.0445 \\
(-0.93)\end{array}$ & $\begin{array}{l}-0.104 * \\
(-1.81) \\
\end{array}$ & $\begin{array}{c}-0.0951^{*} \\
(-1.74) \\
\end{array}$ & $\begin{array}{l}-0.110^{*} \\
(-1.95) \\
\end{array}$ & $\begin{array}{l}-0.102 * \\
(-1.95) \\
\end{array}$ & $\begin{array}{l}-0.0172 \\
(-0.30) \\
\end{array}$ & $\begin{array}{c}-0.00776 \\
(-0.15)\end{array}$ \\
\hline Emp_cons, lag & $\begin{array}{l}-0.127^{*} \\
(-1.84)\end{array}$ & $\begin{array}{l}-0.124^{*} \\
(-1.75)\end{array}$ & $\begin{array}{c}-0.390^{* *} \\
(-2.15)\end{array}$ & $\begin{array}{c}-0.375^{* *} \\
(-2.04)\end{array}$ & $\begin{array}{c}-0.290^{* *} \\
(-2.43)\end{array}$ & $\begin{array}{c}-0.277^{* *} \\
(-2.34)\end{array}$ & $\begin{array}{l}-0.106 \\
(-1.45)\end{array}$ & $\begin{array}{l}-0.102 \\
(-1.39)\end{array}$ & $\begin{array}{c}-0.0981^{*} \\
(-1.68)\end{array}$ & $\begin{array}{c}-0.101^{*} \\
(-1.68)\end{array}$ & $\begin{array}{l}-0.0802 \\
(-1.49)\end{array}$ & $\begin{array}{l}-0.0844 \\
(-1.52)\end{array}$ & $\begin{array}{l}-0.0254 \\
(-0.49)\end{array}$ & $\begin{array}{l}-0.0336 \\
(-0.65)\end{array}$ & $\begin{array}{c}0.00311 \\
(0.06)\end{array}$ & $\begin{array}{c}-0.00906 \\
(-0.16)\end{array}$ & $\begin{array}{l}-0.0136 \\
(-0.20)\end{array}$ & $\begin{array}{l}-0.0348 \\
(-0.52)\end{array}$ \\
\hline Emp_finan., lag & $\begin{array}{l}0.0681 \\
(0.92)\end{array}$ & $\begin{array}{l}0.0566 \\
(0.78)\end{array}$ & $\begin{array}{l}-0.0908 \\
(-0.66)\end{array}$ & $\begin{array}{l}-0.0789 \\
(-0.58)\end{array}$ & $\begin{array}{l}-0.0499 \\
(-0.51)\end{array}$ & $\begin{array}{l}-0.0530 \\
(-0.56)\end{array}$ & $\begin{array}{l}0.0396 \\
(0.54)\end{array}$ & $\begin{array}{l}0.0219 \\
(0.30)\end{array}$ & $\begin{array}{l}0.101 \\
(1.53)\end{array}$ & $\begin{array}{l}0.0770 \\
(1.21)\end{array}$ & $\begin{array}{l}0.0893 \\
(1.32)\end{array}$ & $\begin{array}{l}0.0790 \\
(1.11)\end{array}$ & $\begin{array}{l}0.120 \\
(1.48)\end{array}$ & $\begin{array}{l}0.113 \\
(1.24)\end{array}$ & $\begin{array}{l}0.120 \\
(1.07)\end{array}$ & $\begin{array}{l}0.113 \\
(0.89)\end{array}$ & $\begin{array}{l}0.177 \\
(1.30)\end{array}$ & $\begin{array}{l}0.164 \\
(1.04)\end{array}$ \\
\hline Emp_gov, lag & $\begin{array}{l}0.0497 \\
(1.54)\end{array}$ & $\begin{array}{l}0.0476 \\
(1.37)\end{array}$ & $\begin{array}{l}0.116^{*} \\
(1.86)\end{array}$ & $\begin{array}{l}0.0953 \\
(1.35)\end{array}$ & $\begin{array}{c}0.0824^{*} \\
(1.71)\end{array}$ & $\begin{array}{l}0.0711 \\
(1.38)\end{array}$ & $\begin{array}{l}0.0394 \\
(1.12)\end{array}$ & $\begin{array}{l}0.0391 \\
(1.08)\end{array}$ & $\begin{array}{l}0.0365 \\
(1.28)\end{array}$ & $\begin{array}{l}0.0382 \\
(1.24)\end{array}$ & $\begin{array}{l}0.0440 \\
(1.64)\end{array}$ & $\begin{array}{c}0.0496 * \\
(1.74)\end{array}$ & $\begin{array}{c}0.0503^{*} \\
(1.91)\end{array}$ & $\begin{array}{c}0.0605^{* *} \\
(2.22)\end{array}$ & $\begin{array}{l}0.0400 \\
(1.55)\end{array}$ & $\begin{array}{c}0.0549 * * \\
(2.15)\end{array}$ & $\begin{array}{l}0.0356 \\
(1.08)\end{array}$ & $\begin{array}{c}0.0548^{*} \\
(1.75)\end{array}$ \\
\hline Emp_growth, lag & $\begin{array}{c}-0.00103 \\
(-0.20)\end{array}$ & $\begin{array}{c}-0.000458 \\
(-0.09)\end{array}$ & $\begin{array}{c}-0.00333 \\
(-0.25)\end{array}$ & $\begin{array}{c}0.000296 \\
(0.02)\end{array}$ & $\begin{array}{c}0.000845 \\
(0.09)\end{array}$ & $\begin{array}{c}0.00181 \\
(0.21)\end{array}$ & $\begin{array}{c}0.000551 \\
(0.11)\end{array}$ & $\begin{array}{c}0.000906 \\
(0.18)\end{array}$ & $\begin{array}{c}-0.00000434 \\
(-0.00)\end{array}$ & $\begin{array}{c}0.000281 \\
(0.06)\end{array}$ & $\begin{array}{c}0.000376 \\
(0.10)\end{array}$ & $\begin{array}{c}0.000192 \\
(0.05)\end{array}$ & $\begin{array}{c}-0.00193 \\
(-0.48)\end{array}$ & $\begin{array}{c}-0.00224 \\
(-0.56)\end{array}$ & $\begin{array}{c}-0.00136 \\
(-0.34)\end{array}$ & $\begin{array}{c}-0.00181 \\
(-0.45)\end{array}$ & $\begin{array}{c}-0.00265 \\
(-0.45)\end{array}$ & $\begin{array}{c}-0.00380 \\
(-0.73)\end{array}$ \\
\hline Fertility, lag & $\begin{array}{c}-0.0426 * * * \\
(-4.89)\end{array}$ & $\begin{array}{c}-0.0434 * * * \\
(-4.82)\end{array}$ & $\begin{array}{c}-0.0345 * * \\
(-2.13)\end{array}$ & $\begin{array}{c}-0.0385 * * \\
(-2.25)\end{array}$ & $\begin{array}{c}-0.0453^{* * *} \\
(-3.19)\end{array}$ & $\begin{array}{c}=-0.0470^{* * * *} \\
(-3.32)\end{array}$ & $\begin{array}{c}-0.0598 * * * \\
(-6.22)\end{array}$ & $\begin{array}{c}-0.0609 * * * \\
\quad(-6.21)\end{array}$ & $\begin{array}{c}*-0.0480^{* * *}- \\
(-5.83)\end{array}$ & $\begin{array}{c}-0.0483^{* * *} \\
(-5.57)\end{array}$ & $\begin{array}{c}-0.0443^{* * * *} \\
\quad(-5.75)\end{array}$ & $\begin{array}{c}-0.0438^{* * *} \\
(-5.51)\end{array}$ & $\begin{array}{c}* 0.0298^{* * *} \\
(-4.14)\end{array}$ & $\begin{array}{c}-0.0284^{* * * *} \\
(-3.87)\end{array}$ & $\begin{array}{c}*-0.0231^{* * *} \\
(-3.43)\end{array}$ & $\begin{array}{c}*-0.0217 * * * \\
(-3.32)\end{array}$ & $\begin{array}{c}-0.0275 * * \\
(-2.11)\end{array}$ & $\begin{array}{c}-0.0247 * * \\
(-1.99)\end{array}$ \\
\hline Welfare, lag & $\begin{array}{l}-0.111 \\
(-1.08) \\
\end{array}$ & $\begin{array}{l}-0.127 \\
(-1.21) \\
\end{array}$ & $\begin{array}{l}0.0419 \\
(0.18) \\
\end{array}$ & $\begin{array}{l}-0.0464 \\
(-0.19) \\
\end{array}$ & $\begin{array}{l}-0.132 \\
(-0.78) \\
\end{array}$ & $\begin{array}{l}-0.160 \\
(-0.93) \\
\end{array}$ & $\begin{array}{r}-0.102 \\
(-0.94) \\
\end{array}$ & $\begin{array}{l}-0.116 \\
(-1.04) \\
\end{array}$ & $\begin{array}{l}-0.124 \\
(-1.27) \\
\end{array}$ & $\begin{array}{l}-0.137 \\
(-1.37) \\
\end{array}$ & $\begin{array}{r}-0.138 \\
(-1.57) \\
\end{array}$ & $\begin{array}{l}-0.135 \\
(-1.58) \\
\end{array}$ & $\begin{array}{r}-0.134 \\
(-1.52) \\
\end{array}$ & $\begin{array}{l}-0.121 \\
(-1.51) \\
\end{array}$ & $\begin{array}{l}-0.0922 \\
(-1.09) \\
\end{array}$ & $\begin{array}{l}-0.0733 \\
(-0.96) \\
\end{array}$ & $\begin{array}{l}-0.250^{* *} \\
(-2.59) \\
\end{array}$ & $\begin{array}{l}-0.229 * * \\
(-2.33) \\
\end{array}$ \\
\hline Num.Obs. & 240 & 240 & 240 & 240 & 240 & 240 & 240 & 240 & 240 & 240 & 240 & 240 & 240 & 240 & 240 & 240 & 240 & 240 \\
\hline hansen (p-val) & 0.514 & 0.694 & 0.736 & 0.879 & 0.575 & 0.814 & 0.439 & 0.664 & 0.413 & 0.589 & 0.396 & 0.668 & 0.481 & 0.707 & 0.470 & 0.657 & 0.586 & 0.710 \\
\hline m1(p-val) & 0.000 & 0.000 & 0.000 & 0.000 & 0.000 & 0.000 & 0.000 & 0.000 & 0.000 & 0.000 & 0.000 & 0.000 & 0.000 & 0.000 & 0.000 & 0.000 & 0.000 & 0.000 \\
\hline m2(p-val) & 0.208 & 0.275 & 0.168 & 0.306 & 0.120 & 0.178 & 0.161 & 0.201 & 0.204 & 0.219 & 0.847 & 0.742 & 0.893 & 0.672 & 0.596 & 0.799 & 0.469 & 0.371 \\
\hline AR(3)(p-val) & 0.122 & 0.110 & 0.181 & 0.139 & 0.0334 & 0.0380 & 0.0384 & 0.0371 & 0.159 & 0.155 & 0.314 & 0.340 & 0.521 & 0.685 & 0.360 & 0.514 & 0.906 & 0.656 \\
\hline Num.States & 48 & 48 & 48 & 48 & 48 & 48 & 48 & 48 & 48 & 48 & 48 & 48 & 48 & 48 & 48 & 48 & 48 & 48 \\
\hline Num.Instr. & 60 & 65 & 60 & 65 & 60 & 65 & 60 & 65 & 60 & 65 & 60 & 65 & 60 & 65 & 60 & 65 & 60 & 65 \\
\hline
\end{tabular}

See note Table 5 